OPEN ACCESS

Edited by:

Zeynep Cetecioglu,

Royal Institute of Technology, Sweden

Reviewed by:

loannis Vyrides,

Cyprus University of Technology,

Cyprus

Seung Gu Shin,

Pohang University of Science and Technology, South Korea

${ }^{*}$ Correspondence:

Victor S. Garcia Rea V.S.GarciaRea@tudelft.nl; serman13@hotmail.com

Specialty section: This article was submitted to

Microbiotechnology,

a section of the journa

Frontiers in Microbiology

Received: 08 September 2020 Accepted: 29 October 2020

Published: 30 November 2020

Citation:

García Rea VS, Muñoz Sierra JD,

Fonseca Aponte LM

Cerqueda-Garcia D, Quchani KM,

Spanjers H and van Lier JB (2020) Enhancing Phenol Conversion Rates

in Saline Anaerobic Membrane

Bioreactor Using Acetate and Butyrate as Additional Carbon and Energy Sources.

Front. Microbiol. 11:604173. doi: 10.3389/fmicb.2020.604173

\section{Enhancing Phenol Conversion Rates in Saline Anaerobic Membrane Bioreactor Using Acetate and Butyrate as Additional Carbon and Energy Sources}

Víctor S. García Rea ${ }^{1 *}$, Julian D. Muñoz Sierra ${ }^{1,2}$, Laura M. Fonseca Aponte', Daniel Cerqueda-Garcia ${ }^{3}$, Kiyan M. Quchani ${ }^{1}$, Henri Spanjers ${ }^{1}$ and Jules B. van Lier ${ }^{1}$

\footnotetext{
'Sanitary Engineering Section, Department of Water Management, Delft University of Technology, Delft, Netherlands, ${ }^{2}$ KWR Water Research Institute, Nieuwegein, Netherlands, ${ }^{3}$ Institute of Ecology, National Autonomous University of Mexico, Mexico City, Mexico
}

Phenolic industrial wastewater, such as those from coal gasification, are considered a challenge for conventional anaerobic wastewater treatment systems because of its extreme characteristics such as presence of recalcitrant compounds, high toxicity, and salinity. However, anaerobic membrane bioreactors (AnMBRs) are considered of potential interest since they retain all micro-organism that are required for conversion of the complex organics. In this study, the degradation of phenol as main carbon and energy source (CES) in AnMBRs at high salinity $\left(8.0 \mathrm{~g} \mathrm{Na}^{+} \cdot \mathrm{L}^{-1}\right)$ was evaluated, as well as the effect of acetate and an acetate-butyrate mixture as additional CES on the specific phenol conversion rate and microbial community structure. Three different experiments in two lab-scale $(6.5 \mathrm{~L})$ AnMBRs $\left(35^{\circ} \mathrm{C}\right)$ were conducted. The first reactor (R1) was fed with phenol as the main CES, the second reactor was fed with phenol and either acetate [2 $\left.\mathrm{g} \mathrm{COD} \cdot \mathrm{L}^{-1}\right]$, or a 2:1 acetate-butyrate [2 $\mathrm{g}$ COD. $L^{-1}$ ] mixture as additional CES. Results showed that phenol conversion could not be sustained when phenol was the sole CES. In contrast, when the reactor was fed with acetate or an acetate-butyrate mixture, specific phenol conversion rates of 115 and $210 \mathrm{mgPh} \cdot \mathrm{gVSS}^{-1} \mathrm{~d}^{-1}$, were found, respectively. The syntrophic phenol degrader Syntrophorhabdus sp. and the acetoclastic methanogen Methanosaeta sp. were the dominant bacteria and archaea, respectively, with corresponding relative abundances of up to 63 and $26 \%$. The findings showed that dosage of additional CES allowed the development of a highly active phenol-degrading biomass, potentially improving the treatment of industrial and chemical wastewaters.

Keywords: phenol, anaerobic membrane bioreactor, enhanced phenol conversion rate, acetate, butyrate, microbial community, Syntrophorhabdus sp. 


\section{INTRODUCTION}

Rapid industrialization has generated many industrial effluents that constitute a major source of pollution (Lin et al., 2013). Currently, many of these industrial effluents are successfully treated using anaerobic high-rate treatment processes (Van Lier et al., 2015). However, some industrial wastewaters represent a challenge for conventional anaerobic wastewater treatment systems. Wastewater characteristics that are considered extreme, such as high organic pollutant concentration, presence of recalcitrant or refractory as well as toxic or inhibitory compounds, and high salinity, reduce the performance of conventional anaerobic systems, which leads to process imbalance or reactor failure (Dereli et al., 2012). Dereli et al. (2012), proposed the use of anaerobic membrane bioreactors (AnMBR) to treat industrial wastewater with extreme characteristics, especially because of their effective biomass retention and the production of suspended-solids-free effluents, making them suitable for water reclamation.

Chemical and petrochemical wastewater, such as coal gasification, is an example of an industrial effluent with toxic phenolics as the major organic pollutants ( $\mathrm{Li}$ et al., 2017). Nevertheless, other compounds such as acetate or butyrate, which could be used by microorganisms as carbon and energy sources (CES), are also present in coal gasification wastewater as common contaminants (Singer et al., 1978; Blum et al., 1986; Ji et al., 2016). Besides, it has been reported that coalrelated industries wastewaters have a high concentration of total dissolved solids, ranging from 174 to $2,000 \mathrm{mg} \cdot \mathrm{L}^{-1}$ (Maiti et al., 2019). Furthermore, under closed-water-loops, increasing salinity in the wastewater is expected.

Several studies have researched the anaerobic degradation of phenol, as well in some studies different CES have been used to promote or enhance the degradation of phenol under anaerobic conditions (Liang and Fang, 2010), e.g., glucose (Tay et al., 2001), volatile fatty acids (VFAs) (Carbajo et al., 2010), or acetate (Muñoz Sierra et al., 2017). Additional CES have been used as well during the reactor start-up, or for the degradation of mixtures of phenolic compounds. However, in most of these studies, it remains unclear how and to what extent these substrates promoted or increased phenol degradation.

We have identified four possible mechanisms that could explain the effect of additional CES on the degradation of toxic or inhibitory compounds: 1 . Co-metabolism, a process that was initially defined as the catabolic degradation of a recalcitrant substrate without using the generated energy to promote or sustain cell growth (Horvath, 1972). In this process, the degradation of the non-easily degradable compound is dependent on the presence of a main substrate, or primary source, which is commonly an easily degradable compound (Horvath, 1972; Bertrand et al., 2015). However, (Wackett, 1996) attributed the enhancement in the conversion rate to an unknown or unidentified effect in the metabolic net between the different microbial populations, which are present in nondefined mixed cultures.

2. Direct usage of additional CES by the toxicant degraders to increase their metabolic capability (Kennes et al., 1997; Tay et al., 2001; Gali et al., 2006). Meaning that: a) additional CES could be used as a substrate to increase the anabolism of the degraders, promoting its growth, thus increasing its fraction in the biomass. b) Increasing the catabolic activity (i.e., uptake rate) of the degraders; or c) both processes are increased (Supplementary Material S1). This would imply, e.g., for phenol, that phenol degraders could use another (easily biodegradable) CES. The latter contrasts to the general comprehension that in anaerobic digestion (AD) process, specific (physiological) microbial populations have well-defined narrow substrate ranges (Batstone et al., 2002).

3. Effect of syntrophy on the thermodynamics of compound degradation. In the case of phenol conversion, a constant level of hydrogen consumption is required, which serves as an electron sink for favorable thermodynamics conditions (Qiu et al., 2008). Therefore, the development of a sound hydrogenotrophic methanogenic subpopulation is indispensable for establishing efficient anaerobic oxidation of aromatics and/or their degradation products.

4. An increase in intermediate compounds involved in the conversion of phenolics. Phenol degradation under anoxic conditions occurs via carboxylation of the phenolic ring to form 4-hydroxybenzoate (Schink et al., 2000; Gibson and Harwood, 2002; Fuchs et al., 2011). It has been reported that under strict anaerobic (methanogenic) conditions, phenol degradation is dependent on a sufficiently high $\mathrm{CO}_{2} / \mathrm{HCO}_{3}{ }^{-}$ and $\mathrm{H}_{2}$ concentration (Knoll and Winter, 1987; Karlsson et al., 1999; Fuchs, 2008). Veeresh et al. (2005) reported that dosage of additional CES increased the phenol-degrading activity of the biomass, hypothesizing that this was due to a higher phenol hydrogenation rate, resulting in a better cleavage of the phenolic ring.

In contrast to these four mechanisms, addition of an extra CES, such as acetate, has been shown to inhibit the anaerobic degradation of terephthalic acid (Kleerebezem, 1999.), which even though is not a phenolic compound, shares the same degradation pathway (under anoxic/anaerobic conditions) with phenol (Nobu et al., 2015). So, the effect of CESs' dosage on the degradation of recalcitrant and toxic or inhibitory compounds is not fully understood. Moreover, there is few information regarding the effect of the dosage of CES on the specific phenol conversion rate (sPhCR), especially in AnMBRs under saline conditions.

As well, little is known regarding the microbial community structure and dynamics in AnMBRs under saline conditions treating toxic compounds such as phenol. Furthermore, no study has been conducted to determine how the microbial community is shifted by either the increase in the loading rates and/or the addition of extra CES, especially in suspended biomass systems as the one present in the AnMBR.

This study researched the effect of the addition of acetate or a mixture of acetate-butyrate as additional CES on the sPhCR of AnMBRs and on the microbial community related to the degradation process, with particular focus on the phenol degraders and the methanogens. The effect of phenol on the acetotrophic specific methanogenic activity (SMA) and the sPhCR in batch experiments were assessed as well. 


\section{MATERIALS AND METHODS}

\section{Analytical Techniques Chemical Oxygen Demand}

During the operation of the reactors, COD in the feed and the permeate was measured using a spectrophotometer (DR3900, Hach Lange, Germany). Hach Lange Kits (Hach Lange, Germany) were used following the instructions of the manufacturer. Proper dilutions were done to avoid $\mathrm{Cl}^{-}$interference.

\section{Phenol, Volatile Fatty Acids, and Benzoate Concentrations}

Phenol, VFAs, and benzoate were measured by a gas chromatograph (GC) (Agilent Technology) equipped with a flame ionization detector (FID) with a capillary column (type HP-PLOT/U) with a size of $25 \mathrm{~m} \times 320 \mathrm{~mm} \times 0.5 \mathrm{~mm}$. Helium was used as carrier gas at a flow rate of $67 \mathrm{~mL} \cdot \mathrm{min}^{-1}$ and a split ratio of 25:1. The oven temperature was increased from 80 to $180^{\circ} \mathrm{C}$ in $10.5 \mathrm{~min}$. Injector and detector temperatures were 80 and $240^{\circ} \mathrm{C}$, respectively, and the injection volume was $1 \mu \mathrm{L}$.

For the preparation of the samples, approximately $1 \mathrm{~mL}$ of permeate was filtered through a $0.45 \mu \mathrm{m}$ filter (Chromafil Xtra PES-45/25). Depending on the dilution required to have phenol, VFAs, and benzoate in the measurable range of the GC, a certain volume of the filtrate was mixed with pentanol $\left(320 \mathrm{mg} \cdot \mathrm{L}^{-1}\right)$ to obtain a final volume of $1.5 \mathrm{~mL}$. Finally, $10 \mu \mathrm{L}$ of formic acid (95\%) (Merck, Germany) were added to the vial. Phenol concentration was double-checked with a spectrophotometer (Merck, Germany) using Merck - Spectroquant Phenol cell kits (Merck, Germany) following manufacturers' instructions.

\section{Batch Tests}

Specific Methanogenic Activity Inhibition by Phenol Batch tests with initial phenol concentrations of $50(n=2)$, $200(n=6)$, and $500(n=6) \mathrm{mg} \cdot \mathrm{L}^{-1}$ were carried out in $250 \mathrm{~mL}$ Schott glass (Schott, Germany) reactors. Biomass samples $(60-80 \mathrm{~mL})$ were taken from the AnMBR to have a final volume of $200 \mathrm{~mL}$ at a VSS concentration of $4 \mathrm{~g} \cdot \mathrm{L}^{-1}$ (Inoculum/Substrate $=2$ for the control with $2.0 \mathrm{gAc}-\mathrm{COD} \cdot \mathrm{L}^{-1}$ ). Macro- and micronutrients, phosphate buffer solutions, and $\mathrm{Na}^{+}$as $\mathrm{NaCl}$ were dosed as specified in section "Experimental Setup and Reactors Operation." A shaker (New Brunswick ${ }^{\mathrm{TM}}$, Eppendorf, Germany) at $130 \mathrm{rpm}$ and at $35^{\circ} \mathrm{C}$ was used for the incubation. Methane production was continuously measured by an AMPTS (Bioprocess Control, Sweden) following manufacturer's instruction. The tests were stopped when the acetate was completely depleted after $48-72 \mathrm{~h}$ approximately.

\section{Phenol Degradation Tests}

Batch tests with a phenol concentration of $500 \mathrm{mg} \cdot \mathrm{L}^{-1}(n=5)$ were performed. The batch tests were conducted in $250 \mathrm{~mL}$ Schott (Schott, Germany) glass reactors. Biomass was taken from the AnMBR to have a final VSS concentration of $4 \mathrm{~g} \cdot \mathrm{L}^{-1}$. The batch reactors were supplemented with macroand micronutrient solution, phosphate buffer solutions, and $\mathrm{Na}^{+}$(as $\mathrm{NaCl}$ ) as specified in section "Experimental Setup and Reactors Operation." The bottles were incubated at $35^{\circ} \mathrm{C}$ and
$130 \mathrm{rpm}$. Samples (1-2 mL) were periodically taken, and phenol concentration was measured.

\section{Experimental Setup and Reactors Operation \\ Anaerobic Membrane Bioreactor Setup}

Two AnMBRs (6.5 L working volume) were used for the continuous experiment. Figure 1 depicts a scheme of the reactors' setup. The temperature of the reactors was kept at $35.0 \pm 1.0^{\circ} \mathrm{C}$ by a water bath (Tamson Instruments, Netherlands) circulating warm water through the reactor double-jacketed wall. Mixing in the reactor was ensured by internal sludge circulation with a reactor turnover of approximately 200 times $\cdot \mathrm{d}^{-1}$. The setup used two peristaltic pumps (Watson Marlow $12 \mathrm{U} / \mathrm{DV}, 220 \mathrm{Du}$ ) for the feeding solution and permeate extraction, respectively, and one pump (Watson Marlow 620U) for the sludge recirculation. Temperature and $\mathrm{pH}$ were measured online by $\mathrm{pH} /$ temperature probes (Endress \& Hauser Memosens and Mettler Toledo). The biogas production rate was measured by a gas meter counter MGC-1 PMMA (Ritter, Milligas, and MGC-10).

Each reactor was coupled to an external pressure-driven ultrafiltration (nominal pore size of $30 \mathrm{~nm}$ ) PVDF membrane module (X-Flow, Pentair). Membranes were $64 \mathrm{~cm}$ length and $0.52 \mathrm{~cm}$ diameter, and were operated at a cross-flow velocity of $0.8 \mathrm{~m} \cdot \mathrm{s}^{-1}\left(Q \approx 1,450 \mathrm{~L} \cdot \mathrm{d}^{-1}\right)$. Reactors worked at a constant flux of $6 \mathrm{~L} \cdot \mathrm{m}^{-2} \cdot \mathrm{h}^{-1}$. The transmembrane pressure (TMP) was measured by three different pressure sensors (AE Sensors, The Netherlands), with a range of -800 to 600 mbar, that were located at the entrance and outlet of the membrane, and at the permeate side. Reactor volume was controlled by two pressure sensors (AE Sensors, The Netherlands) with a range of 0 to 100 mbar, one was located on top of the reactor to measure the gas pressure, and the other at the bottom of the reactor, to measure the hydrostatic pressure plus the gas pressure.

Biomass was already acclimated to high sodium concentration, and phenol and acetate degradation (Muñoz Sierra et al., 2018). Before starting the continuous experiments, the biomass was mixed and then evenly distributed between the two reactors.

\section{AnMBRs Operation and Model Wastewater Composition}

In the first reactor (R1), phenol was targeted to be, besides the yeast extract, the sole CES. For the second reactor (R2), acetate and a 2:1 acetate-butyrate mixture were added as additional CES (Table 1). Besides the first 10 days of operation of R1 where the HRT was decreased from 7 to $4 \mathrm{~d}$, the HRT in the AnMBRs was maintained at $4 \mathrm{~d}$. The average SRT was calculated as $\mathrm{SRT}=\mathrm{X}_{\text {reactor }}$ ave $[\mathrm{gVSS}] / \mathrm{X}_{\text {removed }}\left[\mathrm{gVSS} \cdot \mathrm{d}^{-1}\right]$, where $\mathrm{X}_{\text {removed }}$ resulted from the biomass withdrawn for samplings divided by the days between each determination of solids. SRT values of $4,300 \pm 1,600(\mathrm{R} 1), 4,500 \pm 1,700 \mathrm{~d}(\mathrm{R} 2 \mathrm{a})$, and 5,300 + 2,040 d (R2b) were found.

For the model wastewater composition, and based on a modification to Hendriks et al. (2018) and Muñoz Sierra et al. (2018), per each gram of COD in the feeding solution, $1.5 \mathrm{~mL}$ of macronutrients solution, $0.76 \mathrm{~mL}$ of micronutrients solution, 


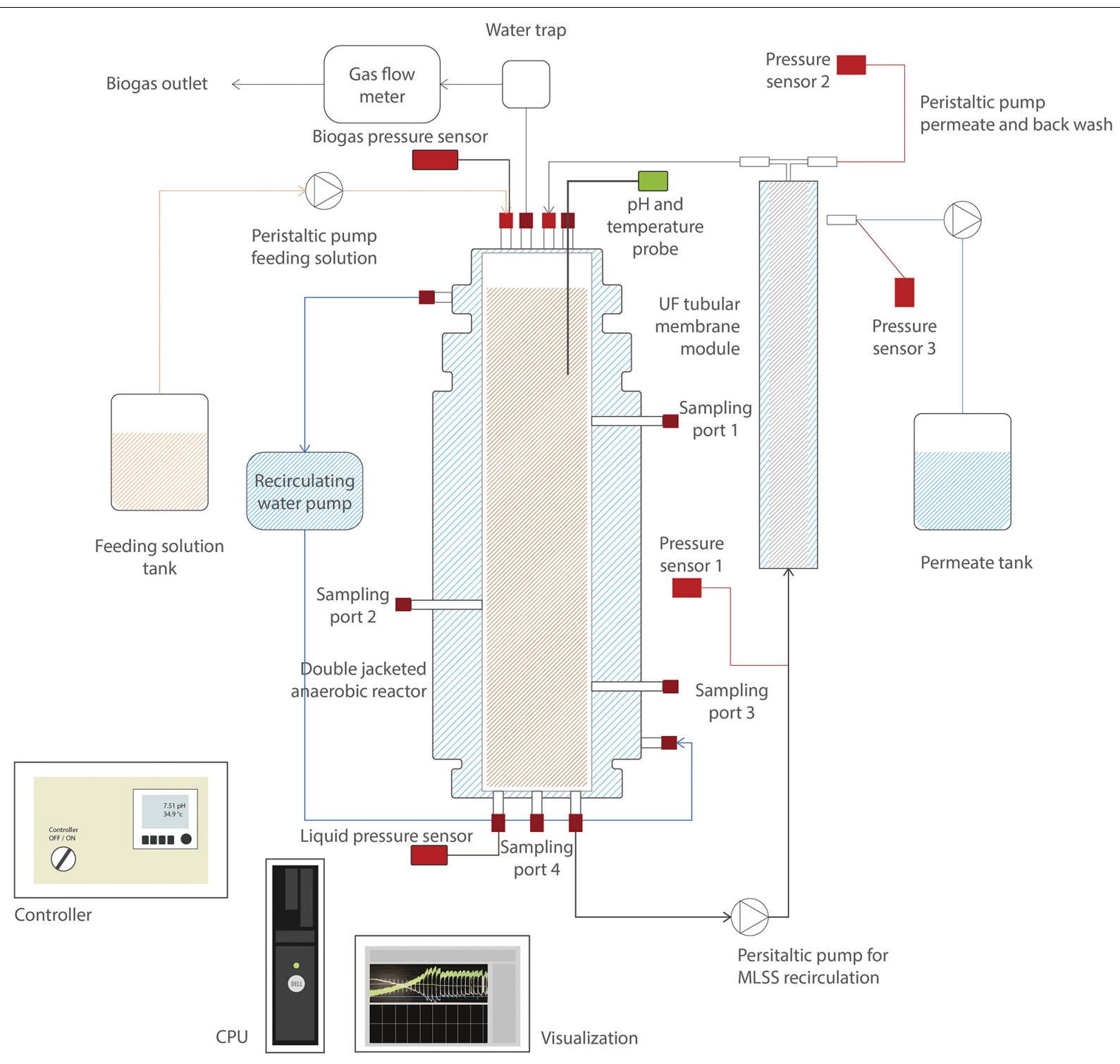

FIGURE 1 | Scheme of the side-stream anaerobic membrane bioreactor (AnMBR) setup.

$2.2 \mathrm{~mL}$ of buffer phosphate solution $\mathrm{A}, 3.4 \mathrm{~mL}$ of buffer phosphate solution $\mathrm{B}$, and $50 \mathrm{mg}$ of yeast extract (Sigma Aldrich) were added, as well, to the feeding solution (Table 2). Enough $\mathrm{NaCl}$ was added to the feeding to keep a $\mathrm{Na}^{+}$concentration of $8.0 \mathrm{~g} \cdot \mathrm{L}^{-1}$.

\section{Microbial Community Analysis DNA Extraction, Quantification, and Amplification}

Biomass samples corresponding to $1.5-2.0 \mathrm{~mL}$ of MLSS were regularly taken from the AnMBRs during the operation of the reactors. The biomass was transferred to Eppendorf tubes (Eppendorf, Germany) and centrifuged in a microcentrifuge (Eppendorf, Germany) at 10,000 $\mathrm{g}$ for $5 \mathrm{~min}$. The supernatant was discarded and the biomass pellets were frozen and stored at $-80^{\circ} \mathrm{C}$. For the DNA extraction, the biomass pellet were thawed, and the DNA was extracted with the DNeasy UltraClean
Microbial Kit (Qiagen, Germany). Qubit3.0 DNA detection (Qubit dsDNA HS assay kit, Life Technologies, United States) was used to verify DNA quality and quantity.

DNA (16S rRNA gene) amplification was done by Illumina Novaseq 6000 platform by Novogene. The hypervariable regions $\mathrm{V} 3-\mathrm{V} 4$ were amplified using the primer set $341 \mathrm{~F}$ $\left[\left(5^{\prime}-3^{\prime}\right)\right.$ CCTAYGGGRBGCASCAG] and 806R $\left[\left(5^{\prime}-3^{\prime}\right)\right.$ GGACTACNNGGGTATCTAAT]. The PCR reactions were carried out with Phusion High- Fidelity PCR Master Mix (New England Biolabs).

\section{DNA Data Processing}

The paired-end reads $(2 \times 250)$ were processed in the QIIME2 pipeline (Bolyen et al., 2019). After manual inspection, the forward and reverse reads were truncated in the position 250 
TABLE 1 | Influent concentration and loading rates of the different carbon sources during the operation of the AnMBRs.

\begin{tabular}{|c|c|c|c|c|c|c|c|c|}
\hline Reactor & Stages & Operation day & $\begin{array}{l}\text { Phenol } \\
{\left[g \cdot L^{-1}\right]}\end{array}$ & $\begin{array}{l}\text { Phenol loading } \\
\text { rate } \\
{\left[\mathrm{mgPh} \cdot \mathrm{gVSS}^{-1} \mathrm{~d}^{-1}\right]}\end{array}$ & $\begin{array}{c}\text { Acetate } \\
{\left[g C O D \cdot L^{-1}\right]}\end{array}$ & $\begin{array}{c}\text { Acetate } \\
\text { loading rate } \\
\text { [gCOD- } \\
\left.\text { Ac.gVSS }{ }^{-1} d^{-1}\right]\end{array}$ & $\begin{array}{c}\text { Butyrate } \\
{\left[g C O D \cdot L^{-1}\right]}\end{array}$ & $\begin{array}{c}\text { Butyrate loading } \\
\text { rate [gCOD- } \\
\left.\text { Bu.gVSS }{ }^{-1} d^{-1}\right]\end{array}$ \\
\hline \multirow[t]{3}{*}{$\mathrm{R} 1$} & 1 & $0-59$ & 0.5 & $10,28,42$ & $\begin{array}{c}4.7,3.5,1.2,0.3 \\
0\end{array}$ & $\begin{array}{c}100,76,25,7 \\
0\end{array}$ & N/A & $\mathrm{N} / \mathrm{A}$ \\
\hline & $\|$ & 60-99 & $0.5,0.9,0.5$ & $42,52,31$ & 0 & 0 & $\mathrm{~N} / \mathrm{A}$ & $\mathrm{N} / \mathrm{A}$ \\
\hline & III & $100-115$ & 0 & 0 & 2.5 & 54 & $\mathrm{~N} / \mathrm{A}$ & $\mathrm{N} / \mathrm{A}$ \\
\hline \multirow[t]{3}{*}{$\mathrm{R} 2$ (a) } & I & $0-43$ & 0.5 & 25 & $4.7,3.5,2.3,2.0$ & $\begin{array}{c}236,177,113 \\
100\end{array}$ & $\mathrm{~N} / \mathrm{A}$ & $\mathrm{N} / \mathrm{A}$ \\
\hline & $\|$ & $44-100$ & $\begin{array}{c}0.5,1.5,3.0 \\
\quad 6.0,8.2\end{array}$ & $\begin{array}{c}25,75,115,230 \\
317\end{array}$ & 2.0 & 100,75 & $\mathrm{~N} / \mathrm{A}$ & $\mathrm{N} / \mathrm{A}$ \\
\hline & III & $101-115$ & 0.0 & 0 & 9.1 & 350 & $\mathrm{~N} / \mathrm{A}$ & N/A \\
\hline \multirow[t]{2}{*}{$\mathrm{R} 2$ (b) } & I & $0-30$ & 0.5 & $\approx 17$ & 1.33 & $\approx 48$ & 0.66 & $\approx 24$ \\
\hline & $\|$ & $31-110$ & $\begin{array}{l}0.75,1.0,1.5 \\
2.7,6.5,11.1\end{array}$ & $\begin{array}{c}30,42,62,108 \\
195,265\end{array}$ & 1.33 & $\approx 48$ & 0.66 & $\approx 24$ \\
\hline
\end{tabular}

TABLE 2 | Micro- and macro nutrient and buffer solutions dosed in the AnMBRs.

\begin{tabular}{|c|c|}
\hline Solution & Composition \\
\hline Micronutrient & $\begin{array}{l}\text { EDTA-Na }\left[1.0 \mathrm{~g} \cdot \mathrm{L}^{-1}\right], \mathrm{H}_{3} \mathrm{BO}_{3}\left[0.050 \mathrm{~g} \cdot \mathrm{L}^{-1}\right], \mathrm{MnCl}_{2} \cdot 4 \mathrm{H}_{2} \mathrm{O}\left[0.50 \mathrm{~g} \cdot \mathrm{L}^{-1}\right], \mathrm{FeCl}_{3} \cdot 6 \mathrm{H}_{2} \mathrm{O}\left[2.0 \mathrm{~g} \cdot \mathrm{L}^{-1}\right], \mathrm{ZnCl}_{2}\left[0.050 \mathrm{~g} \cdot \mathrm{L}^{-1}\right], \mathrm{NiCl}_{2} \cdot 6 \mathrm{H}_{2} \mathrm{O} \\
{\left[0.050 \mathrm{~g} \cdot \mathrm{L}^{-1}\right], \mathrm{CuCl}_{2} \cdot 2 \mathrm{H}_{2} \mathrm{O}\left[0.030 \mathrm{~g} \cdot \mathrm{L}^{-1}\right], \mathrm{Na}_{2} \mathrm{SeO}_{3}\left[0.10 \mathrm{~g} \cdot \mathrm{L}^{-1}\right],\left(\mathrm{NH}_{4}\right)_{6} \mathrm{Mo}_{7} \mathrm{O}_{2} \cdot 4 \mathrm{H}_{2} \mathrm{O}\left[0.090 \mathrm{~g} \cdot \mathrm{L}^{-1}\right], \mathrm{Na}_{2} \mathrm{WO}_{4}\left[0.080 \mathrm{~g} \cdot \mathrm{L}^{-1}\right], \text { and }} \\
\mathrm{CoCl}_{2} \cdot 6 \mathrm{H}_{2} \mathrm{O}\left[2.0 \mathrm{~g} \cdot \mathrm{L}^{-1}\right] .\end{array}$ \\
\hline Macronutrient & $\mathrm{NH}_{4} \mathrm{Cl}\left[170 \mathrm{~g} \cdot \mathrm{L}^{-1}\right], \mathrm{CaCl}_{2} \cdot 2 \mathrm{H}_{2} \mathrm{O}\left[8 \mathrm{~g} \cdot \mathrm{L}^{-1}\right]$, and $\mathrm{MgSO}_{4} \cdot 7 \mathrm{H}_{2} \mathrm{O}\left[9 \mathrm{~g} \cdot \mathrm{L}^{-1}\right]$. \\
\hline Buffer solution A & $\mathrm{K}_{2} \mathrm{HPO}_{4} \cdot 3 \mathrm{H}_{2} \mathrm{O}\left[45.6 \mathrm{~g} \cdot \mathrm{L}^{-1}\right]$ \\
\hline Buffer solution B & $\mathrm{NaH}_{2} \mathrm{PO}_{4} \cdot 2 \mathrm{H}_{2} \mathrm{O}\left[31.2 \mathrm{~g} \cdot \mathrm{L}^{-1}\right]$ \\
\hline
\end{tabular}

in the $3^{\prime}$ end, and the forward reads were trimmed in the position 35 in the $5^{\prime}$ end. Then, the reads were denoised, and the amplicon sequences variants were resolved with the DADA2 plugin (Callahan et al., 2016) removing chimeric sequences with the "consensus" method. The taxonomy of the representative sequences of the amplicon sequences variants was assigned with the classify-consensus-vsearch plugin (Rognes et al., 2016), using the SILVA 132 database (Quast et al., 2013) as reference. The feature table was exported to the $\mathrm{R}$ environment to perform the statistical analysis with the phyloseq library (Mcmurdie and Holmes, 2013). The sequences were deposited in the SRA (NCBI) database under the accession number PRJNA663299.

\section{Canonical Correspondence Analysis}

A canonical correspondence analysis (CCA) was calculated, using the Weighted Unifrac distance metric and the specific phenol loading rate $(\mathrm{sPhLR})$ and $\mathrm{sPhCR}$ as explanatory variables. The statistical significance of the ordination in the CCA was tested with an ANOVA at a $p$-value $<0.05$.

\section{RESULTS AND DISCUSSION}

\section{Acetoclastic SMA Inhibition by Phenol, and Butyrate Degradation Tests}

Batch tests with initial phenol concentrations of 50, 200, and $500 \mathrm{mg} \cdot \mathrm{L}^{-1}$ were performed to determine a possible inhibition by phenol on the acetoclastic SMA of the AnMBR biomass (Figure 2) (Supplementary Material S2,
Supplementary Table S1). At initial phenol concentrations of 50 and $200 \mathrm{mg} \cdot \mathrm{L}^{-1}$, the SMA values were $3.4 \pm 4.8 \%$ and $4.3 \pm 23.6 \%$, respectively, higher than the control (acetate $\left.2.0 \mathrm{~g} \mathrm{COD} \cdot \mathrm{L}^{-1}\right)$, meaning that at these concentrations, there was no inhibition in the acetoclastic methanogens due to phenol. On the other hand, the SMA at an initial phenol concentration of $500 \mathrm{mg} \cdot \mathrm{L}^{-1}$ was $27.0 \pm 6.6 \%$ lower than the control SMA, meaning that the methanogens were inhibited by phenol.

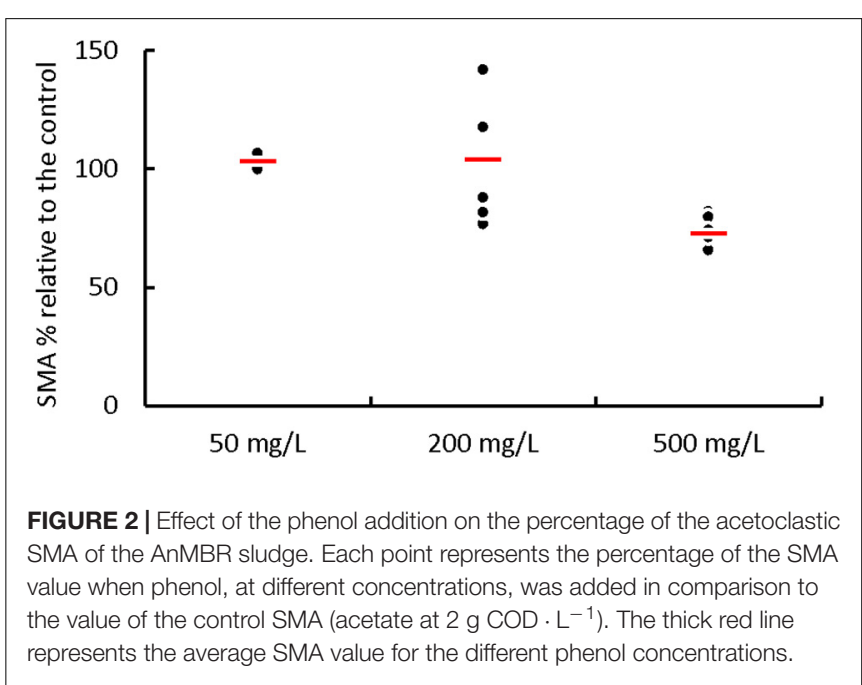




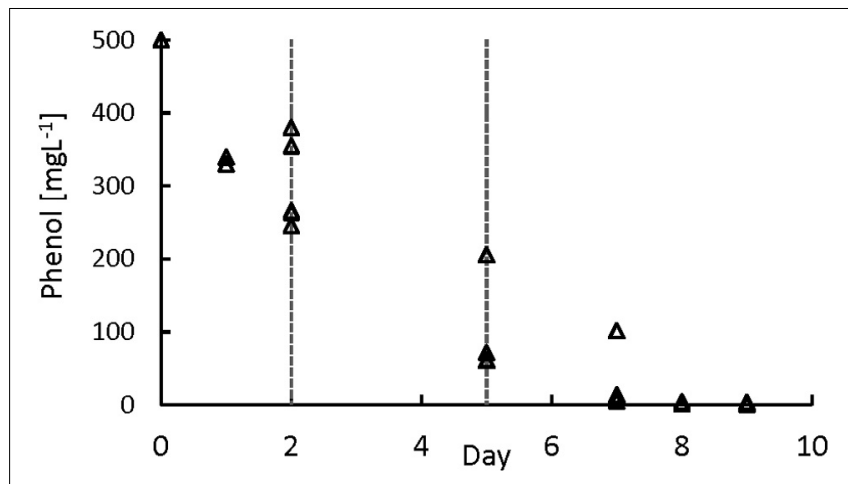

FIGURE 3 | Phenol degradation batch assays. The lines represent the period used for the determination of the specific phenol conversion rate.

$\mathrm{AD}$ inhibition by phenol is a phenomenon reported in literature (Olguin-Lora et al., 2003; Liang and Fang, 2010). Although phenol may affect all main physiological microbial populations of the $\mathrm{AD}$ process, it is reported, as with other inhibitory or toxic substances (Astals et al., 2015), that the acetoclastic methanogenic population could be the most affected group (Chen et al., 2008). Half maximum inhibitory concentration $\left(\mathrm{IC}_{50}\right)$ ranges between 50 and $1,750 \mathrm{mg} \cdot \mathrm{L}^{-1}$ for non-adapted and phenol-degrading biomass have been reported (Fang and Chan, 1997; Olguin-Lora et al., 2003; Collins et al., 2005; Muñoz Sierra et al., 2017).

Furthermore, we performed all batch experiments at $8.0 \mathrm{~g}$ $\mathrm{Na}^{+} \cdot \mathrm{L}^{-1}$ which might have had an impact as well, even though the biomass was adapted to this $\mathrm{Na}^{+}$concentration. In agreement with literature (Fang and Chan, 1997; Olguin-Lora et al., 2003; Collins et al., 2005; Muñoz Sierra et al., 2017), the results obtained in this research showed that a phenol concentration of $50 \mathrm{mg} \cdot \mathrm{L}^{-1}$ caused no negative effect on the SMA when compared to the control without phenol. As well, the average SMA at phenol concentration of $200 \mathrm{mg} \cdot \mathrm{L}^{-1}$ was not affected, but phenol concentration of $500 \mathrm{mg} \cdot \mathrm{L}^{-1}$ decreased the SMA with $27 \%$. Butyrate at a concentration up to $3.0 \mathrm{~g} \mathrm{COD} \cdot \mathrm{L}^{-1}$ did not cause inhibition problems (Supplementary Material S3).

\section{Phenol Degradation in Batch Assays}

To further study the phenol degradation kinetics, a series of batch tests with phenol concentrations of $500 \mathrm{mgPh} \cdot \mathrm{L}^{-1}$ were performed (Figure 3). For calculating the $\mathrm{sPCR}$, the period between day 2 and day 5 of the assays was chosen to get

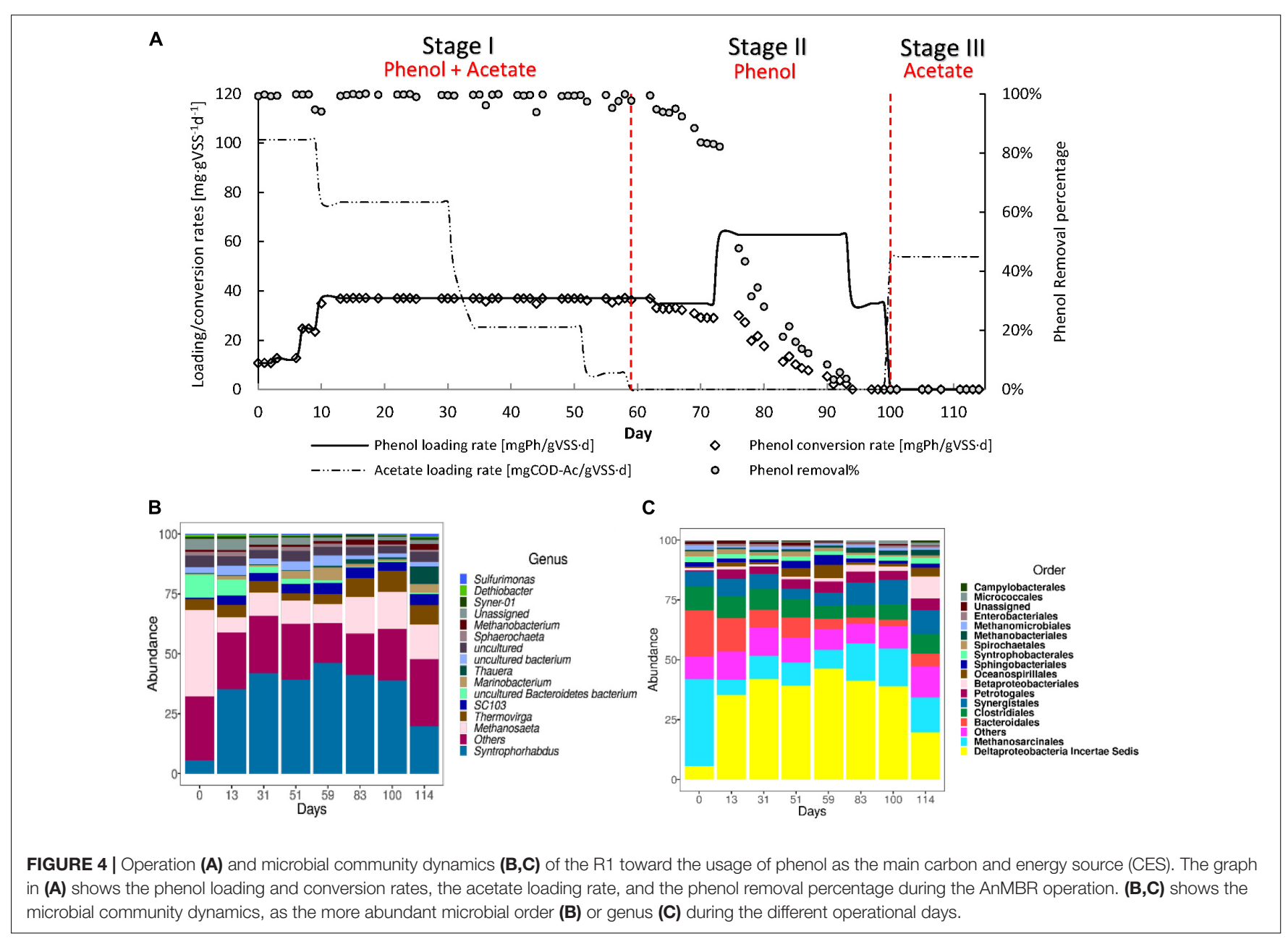


the part of the curve that avoids a possible inhibition of the phenol degraders by high phenol concentration (Supplementary Material S1). The average sPhCRs calculated during the batch test were $17.8 \pm 2.6 \mathrm{mgPh} \cdot \mathrm{gVSS}^{-1} \mathrm{~d}^{-1}$.

Several sPhCR values for granular biomass have been reported in batch tests, such as 126 (Tay et al., 2000), 65 (Razo-Flores et al., 2003), and 38-93 (Fang et al., 2004) mgPh.gVSS ${ }^{-1} \mathrm{~d}^{-1}$ which are higher than the average value of $16.6 \pm 1.9 \mathrm{mgPh} \cdot \mathrm{gVSS}^{-1} \mathrm{~d}^{-1}$ that we obtained. However, in our study, the sPhCRs assessed in the batch tests were lower than the $\mathrm{sPCR}$ determined in the continuous experiment (section “AnMBR Operation”).

\section{AnMBR Operation \\ AnMBR Operation Toward Phenol as the Main Carbon and Energy Source}

R1 was operated to assess whether phenol could serve as the sole CES (Figure 4A) and the maximum sPhCR that could be achieved. During stage I, in which acetate was stepwise decreased and the sPhLR was stepwise increased in ten days from 12 to $42 \mathrm{mgPh} \cdot \mathrm{gVSS}^{-1} \mathrm{~d}^{-1}$. During this period, the $\mathrm{sPhCR}$ remained the same as the $\mathrm{SPhLR}$, i.e., $42 \mathrm{mgPh} \cdot \mathrm{gVSS}^{-1} \mathrm{~d}^{-1}$, corresponding to a phenol removal efficiency exceeding 99\%. In stage II, after the exclusion of acetate from the feeding, the $\mathrm{sPCR}$ decreased to $29 \mathrm{mgPh} \cdot \mathrm{gVSS}^{-1} \mathrm{~d}^{-1}$ during the days 59-72. When the phenol loading was increased to $62 \mathrm{mgPh} \cdot \mathrm{gVSS}^{-1} \mathrm{~d}^{-1}$, the $\mathrm{sPhCR}$ and the removal percentage started to decrease, and on day 94, the sPhCR and the phenol removal efficiency were 0 . During stage III, phenol was excluded from the influent because no phenol conversion was observed, and further intoxication of the reactor biomass was unwanted. Hence, the COD was replaced with acetate.

In our present study, it was not possible to achieve longtime AnMBR operation with phenol as the sole CES. This was confirmed with a second experiment (Supplementary Material S4, Supplementary Figure S1). Possibly, this inability might be attributed to the applied sodium concentration of $8 \mathrm{~g} \cdot \mathrm{L}^{-1}$, which has been hypothesized to decrease the phenol conversion (Wang et al., 2017). Under saline conditions, more of the catabolically generated energy from the substrate conversion, in this case phenol, will be spent on regulating a higher maintenance energy in the biomass, because of the increased osmotic pressure (Russell and Cook, 1995; He et al., 2017). A maximum sPhCR of $40 \mathrm{mgPh} \cdot \mathrm{gVSS}^{-1} \mathrm{~L}^{-1}$ was determined from days 49 to 62 (Stage I) when phenol was the main CES, representing $80 \%$ of the total COD while acetate contributed to $20 \%$ of the COD. However, this sPhCR could not be sustained for more than five days after the acetate was excluded from the influent (Stage II).

For continuous reactor operation, anaerobic degradation of phenol as sole CES at different sPhCRs (6$690 \mathrm{mgPh} \cdot \mathrm{gVSS}^{-1} \mathrm{~d}^{-1}$ ) has been reported (Fang et al., 1996; Kennes et al., 1997; Zhou and Fang, 1997; Razo-Flores et al., 2003; Ramakrishnan and Gupta, 2008; Liang and Fang, 2010)
(Table 3). Most of these studies refer to granular-sludge-based reactors, such as upflow anaerobic sludge blanket (UASB) reactors, under non-saline conditions. As an exception, Suidan et al. (1988), reported the successful continuous operation of a chemostat (suspended biomass) with phenol as the only CES.

An anaerobic granule consists of several populations of microorganisms forming an ecosystem, in which the products of a specific population serves as the substrate for others in a very close vicinity. Moreover, methanogens and phenoldegraders in the inside are only exposed to very low phenol concentrations when phenol is indeed readily degraded in the continuous system. Subsequent phenol conversion in the granule interior provides the conversion intermediates as a substrate for the other populations, allowing the use of phenol as the sole CES. In suspended biomass systems, such as an AnMBR, the phenol concentration is the same for all biomass, while distances between microbial species are much larger, making these systems much more sensitive to increased phenol concentrations.

\section{Effect of the Addition of Acetate on the Specific Phenol Conversion Rate}

R2(a) was operated to determine the effect of the addition of acetate as an extra CES on the sPhCR (Figure 5A). In stage $\mathrm{I}$, the acetate-COD concentration in the influent was decreased from 4.7 to $2.0 \mathrm{gCOD} \mathrm{L}^{-1}$, corresponding to an acetate loading rate of $100 \mathrm{mgAc}-\mathrm{COD} \cdot \mathrm{gVSS}^{-1} \mathrm{~d}^{-1}$, while the $\mathrm{sPhLR}$ was maintained at $25 \mathrm{mgPh} \cdot \mathrm{gVSS}^{-1} \mathrm{~d}^{-1}$, corresponding to a phenol concentration in the influent of $0.5 \mathrm{gPh} \cdot \mathrm{L}^{-1}$. During this stage, the $\mathrm{sPhCR}$ was $25 \mathrm{mgPh} \cdot \mathrm{gVSS}^{-1} \mathrm{~d}^{-1}$, corresponding to a phenol removal percentage of $\approx 100 \%$.

In stage II, the $\mathrm{SPhLR}$ was stepwise increased from 75 to $230 \mathrm{mgPh} \cdot \mathrm{gVSS}^{-1} \mathrm{~d}^{-1}$, corresponding to phenol concentrations in the influent of 1.5 and $8.2 \mathrm{~g} \cdot \mathrm{L}^{-1}$, respectively. Phenol removal of $100 \%$ was observed with phenol loading rates of 75 and $115 \mathrm{mgPh} \cdot \mathrm{gVSS}^{-1} \mathrm{~d}^{-1}$. At a loading rate of $230 \mathrm{mgPh} \cdot \mathrm{gVSS}^{-1} \mathrm{~d}^{-1}$, the sPhCR and the removal efficiency decreased to $86 \mathrm{mgPhg} \cdot \mathrm{VSS}^{-1} \mathrm{~d}^{-1}$ and $55 \%$, respectively. The further increase in the $\operatorname{sPhLR}\left(320 \mathrm{mgPh} \cdot \mathrm{gVSS}^{-1} \mathrm{~d}^{-1}\right)$ on day 87 caused an intoxication of the AnMBR, which was observed as a decreased sPhCR that was eventually halted. During days 94 to 100, phenol in the feeding solution was excluded and acetate concentration was kept at $2.0 \mathrm{~g} \mathrm{COD} \cdot \mathrm{L}^{-1}$. In stage III, the reactor was fed with only acetate at a concentration of $9.1 \mathrm{~g} \mathrm{COD} \cdot \mathrm{L}^{-1}$ to avoid further intoxication of the biomass.

Acetate has been used as an additional CES in the process of biological phenol degradation under anaerobic conditions, either during the reactor start-up (Razo-Flores et al., 2003) or operation (Wang et al., 2017; Muñoz Sierra et al., 2018, 2019) (Table 3). Wang et al. (2017) reported UASB reactors treating synthetic wastewater with acetate concentration of $3.6 \mathrm{~g} \mathrm{COD} \cdot \mathrm{L}^{-1}$ and phenol concentrations ranging from 0.1 to $2.0 \mathrm{~g} \cdot \mathrm{L}^{-1}$, operating under saline conditions with $\mathrm{Na}^{+}$concentration of $10 \mathrm{~g} \cdot \mathrm{L}^{-1}$. They reported 
TABLE 3 | Studies dealing with phenol degradation either as main/unique carbon and energy source or with the dosage of additional carbon and energy sources.

\begin{tabular}{|c|c|c|c|c|c|c|c|c|c|}
\hline Substrate $\left[\mathrm{mg} \cdot \mathrm{L}^{-1}\right]$ & $\begin{array}{c}\text { Sludge PhLR } \\
{\left[\mathrm{gPh} \cdot \mathrm{gVSS} \mathrm{S}^{-1} \mathrm{~d}^{-1}\right]}\end{array}$ & $\begin{array}{c}\text { Total } \\
\text { Removal }\end{array}$ & $\begin{array}{c}\mathrm{sCH}_{4} \text { rate } \\
{\left[\mathrm{L} \cdot \mathrm{gVSS}^{-1} \mathrm{~d}^{-1}\right]}\end{array}$ & $\begin{array}{c}\mathrm{CH}_{4} \text { yield } \\
{\left[\mathrm{LCH}_{4} \cdot \mathrm{g} \mathrm{COD}^{-1}\right]}\end{array}$ & $\begin{array}{c}\mathrm{gCH}_{4-}^{-} \\
\text {COD.gCOD }\end{array}$ & HRT & Vol [L] & Reactor type & References \\
\hline \multicolumn{10}{|c|}{ Phenol degradation with no additional carbon and energy source } \\
\hline Phenol (400) & & $90 \%$ & & 0.21 & $53 \%$ & $0.14 d$ & 0.66 & rUASB & Chang et al. (1995) \\
\hline Phenol $(420-1,260)$ & $0.03-0.09$ & $98 \%$ & 0.075 & 0.35 & $89 \%$ & $12 \mathrm{~h}$ & 2.8 & rUASB & Fang et al. (1996) \\
\hline $\begin{array}{l}\text { Phenol }(2,000) \text { After rec } \\
(250 \text { to } 500)\end{array}$ & 0.58 & $99 \%$ & 0.001 & 0.47 & $117 \%$ & $6 \mathrm{~h}$ & 35 & rUASB & Lay and Cheng (1998) \\
\hline Phenolics (600) & 0.0182 & $30 \%$ & 0.001 & 0.02 & $5 \%$ & $24 \mathrm{~h}$ & 7 & UASB & Wang et al. (2010) \\
\hline Phenol (50-700) & 0.024 & $85 \%$ & 0.024 & 0.415 & $69 \%$ & $24 \mathrm{~h}$ & 2.8 & AFBR & De Amorim et al. (2015) \\
\hline \multicolumn{10}{|c|}{ Additional carbon and energy source dosage for reactor start-up or biomass reactivation } \\
\hline Phenol (234) & 0.006 & $92 \%$ & 0.008 & 0.338 & $86 \%$ & $48 \mathrm{~h}$ & 13.4 & rAF & Li et al. (2016) \\
\hline Phenol $(1,260)$ & 0.26 & $94 \%$ & & 0.308 & $80 \%$ & $12 \mathrm{~h}$ & 2.8 & UASB & Fang et al. (2004) \\
\hline Phenol $(1,260)$ & 0.315 & $86 \%$ & 0.304 & 0.284 & $72 \%$ & $12 \mathrm{~h}$ & 2 & UASB & Tay et al. (2000) \\
\hline \multicolumn{10}{|c|}{ Phenol degradation with additional carbon and energy source dosage } \\
\hline $\begin{array}{l}\text { Phenol }(105-1,260)+ \\
\text { Glucose }\end{array}$ & $0.06-0.28$ & $98 \%$ & & & & $12 \mathrm{~h}$ & 2 & UASB & Tay et al. (2001) \\
\hline $\begin{array}{l}\text { Phenol (625)+ acetate } \\
(3,850)+\mathrm{Na}\left(10 \mathrm{~g} \mathrm{~L}^{-1}\right)\end{array}$ & 0.1042 & $100 \%$ & & & & $48 \mathrm{~h}$ & 3.5 & rUASB-AF & Wang et al. (2017) \\
\hline $\begin{array}{l}\text { Phenol }(1,000)+ \\
\text { Acetate }(1,000)\end{array}$ & & $99 \%$ & & 0.39 & $100 \%$ & $5-2.5 \mathrm{~h}$ & 10 & GAC-AFBR & Lao (2002) \\
\hline $\begin{array}{l}\text { Phenol }(500-1,000)+ \\
\text { VFAs }\end{array}$ & $0.07-0.14$ & $98 \%$ & & 0.32 & $87 \%$ & $12 \mathrm{~h}$ & 3.5 & rEGSB-AF & Scully et al. (2006) \\
\hline Phenol (672)+ VFAs & & $95 \%$ & & 0.28 & $72 \%$ & $0.43 d$ & 1.8 & AFBR & Carbajo et al. (2010) \\
\hline $\begin{array}{l}\text { Phenol }(500)+\text { Acetate } \\
+\mathrm{NaCl} \\
{\left[4.7-20 \mathrm{~g} \mathrm{Na}^{+} \cdot \mathrm{L}^{-1}\right]}\end{array}$ & 0.012 & $99 \%$ & & & & $6.5 d$ & 6.5 & AnMBR & Muñoz Sierra et al. (2018) \\
\hline $\begin{array}{l}\text { Phenol (500) }+\mathrm{NaCl} \\
\left(8 \mathrm{gNa}^{+} \cdot \mathrm{L}^{-1}\right)\end{array}$ & 0.042 & $97 \%$ & 0.036 & - & - & $4 d$ & 6 & $A n M B R$ & This study \\
\hline $\begin{array}{l}\text { Phenol }(3,000)+ \\
\text { Acetate }\left(2 \mathrm{gCOD} \cdot \mathrm{L}^{-1}\right) \\
+\mathrm{NaCl}\left(8 \mathrm{gNa}^{+} \cdot \mathrm{L}^{-1}\right)\end{array}$ & 0.115 & $100 \%$ & 0.114 & 0.27 & $68 \%$ & $4 d$ & 6 & $A n M B R$ & This study \\
\hline $\begin{array}{l}\text { Phenol }(6,500)+ \\
\text { Acetate-Butyrate }(2: 1) \\
\left(2 \mathrm{gCOD} \cdot \mathrm{L}^{-1}\right)+\mathrm{NaCl} \\
\left(8 \mathrm{gNa}^{+} \cdot \mathrm{L}^{-1}\right)\end{array}$ & 0.200 & $100 \%$ & - & - & - & $4 d$ & 6 & $A n M B R$ & This study \\
\hline
\end{tabular}




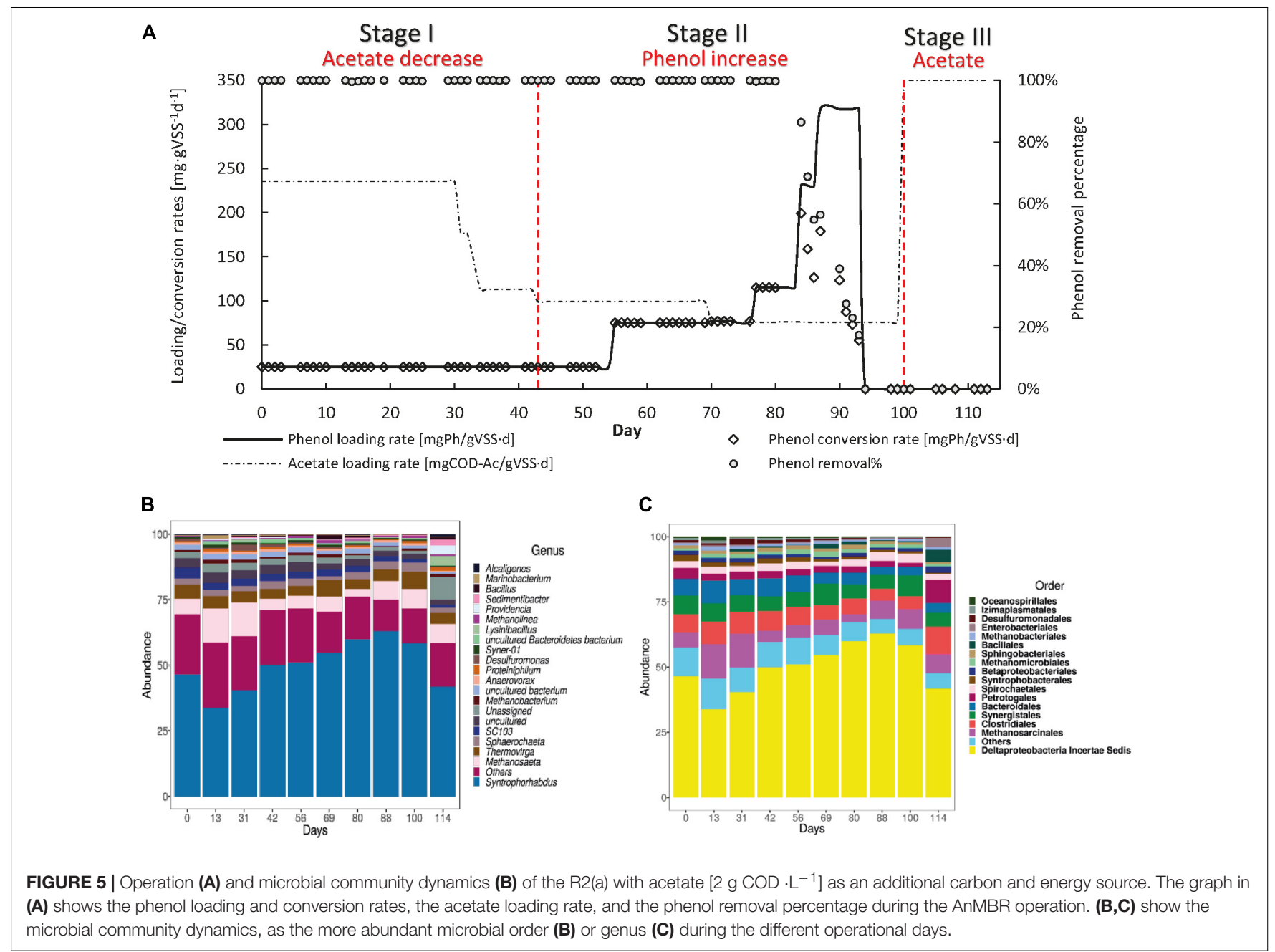

maximum $\mathrm{sPhCR}$ of 20 and $13 \mathrm{mgPh} \cdot \mathrm{gVSS}^{-1} \mathrm{~d}^{-1}$ for batch and continuous reactors, respectively. Working with AnMBRs, Muñoz Sierra et al. (2019), reported maximum sPhCRs of $87 \mathrm{mgPh} \cdot \mathrm{gVSS}^{-1} \mathrm{~d}^{-1}$ at a sodium concentration of $18 \mathrm{~g} \cdot \mathrm{L}^{-1}$, corresponding to concentrations in the influent of $5 \mathrm{~g}$ Phenol. $\mathrm{L}^{-1}$ and an acetate concentration of approximately $30 \mathrm{~g} \mathrm{COD} \cdot \mathrm{L}^{-1}$. For comparison, in this experiment, we found a maximum stable $\mathrm{SPhCR}$ of $115 \mathrm{mgPh} \cdot \mathrm{gVSS}^{-1} \mathrm{~L}^{-1}$ when acetate $\left[2 \mathrm{~g} \mathrm{COD} \cdot \mathrm{L}^{-1}\right.$ ] was used as additional CES.

\section{Effect of the Addition of the Acetate-Butyrate on the Specific Phenol Conversion Rate}

After the recovery of the biomass from phenol intoxication, R2 was fed with a 2:1 acetate-butyrate mixture at a concentration of $2 \mathrm{~g} \mathrm{COD} \cdot \mathrm{L}^{-1}$ to determine the effect of the dosage of an additional CES that intrinsically generates $\mathrm{H}_{2}$ during its conversion on the sPhCR and the phenol degraders and methanogens (Figure 6A). During stage $\mathrm{I}$, the sPhLR was kept at an average value of $17.1 \pm 1.31 \mathrm{mgPh} \cdot \mathrm{gVSS}^{-1} \mathrm{~d}^{-1}$, corresponding to an average phenol concentration in the influent of $0.5 \mathrm{~g} \cdot \mathrm{L}^{-1}$. On day 10 after the dosage of butyrate, the $\mathrm{sPhCR}$ and the phenol removal efficiency decreased to $8.4 \mathrm{mgPh} \cdot \mathrm{gVSS}^{-1} \mathrm{~d}^{-1}$ and $64 \%$, respectively. Possibly, the increased butyrate concentration impacted the phenol conversion pathway. Nobu et al. (2017) indicated that phenol converting microorganisms such as Syntrophorhabdus sp., have an alternative phenol degradation pathway, which yields one molecule of butyrate and one of acetate. Therefore, the increased butyrate concentration in the AnMBR could have decreased phenol degradation by product inhibition (Figure 6A).

During stage II, from day 32 to 98, a phenol removal efficiency of $100 \%$ was found up to a sPhLR (and sPhCR) of $200 \mathrm{mgPh} \cdot \mathrm{gVSS}^{-1} \mathrm{~d}^{-1}$ (influent concentration $6.5 \mathrm{gPh} \cdot \mathrm{L}^{-1}$ ), being amongst the highest anaerobic sPhCRs reported in the literature, and the highest value reported for suspended biomass under anaerobic and saline conditions (Table 3). When the sPhLR was increased to $265 \mathrm{mgPh} \cdot \mathrm{gVSS}^{-1} \mathrm{~d}^{-1}$ (phenol concentration in the influent $=11.1 \mathrm{~g} \cdot \mathrm{L}^{-1}$ ), on day 99 , the $\mathrm{sPhCR}$ and the phenol removal efficiency started to decrease. On day 110 the sPhCR and the removal efficiency had already decreased to $130 \mathrm{mgPh} \cdot \mathrm{gVSS}^{-1} \mathrm{~d}^{-1}$ and $45 \%$, respectively, meaning a reactor failure due to biomass intoxication. 


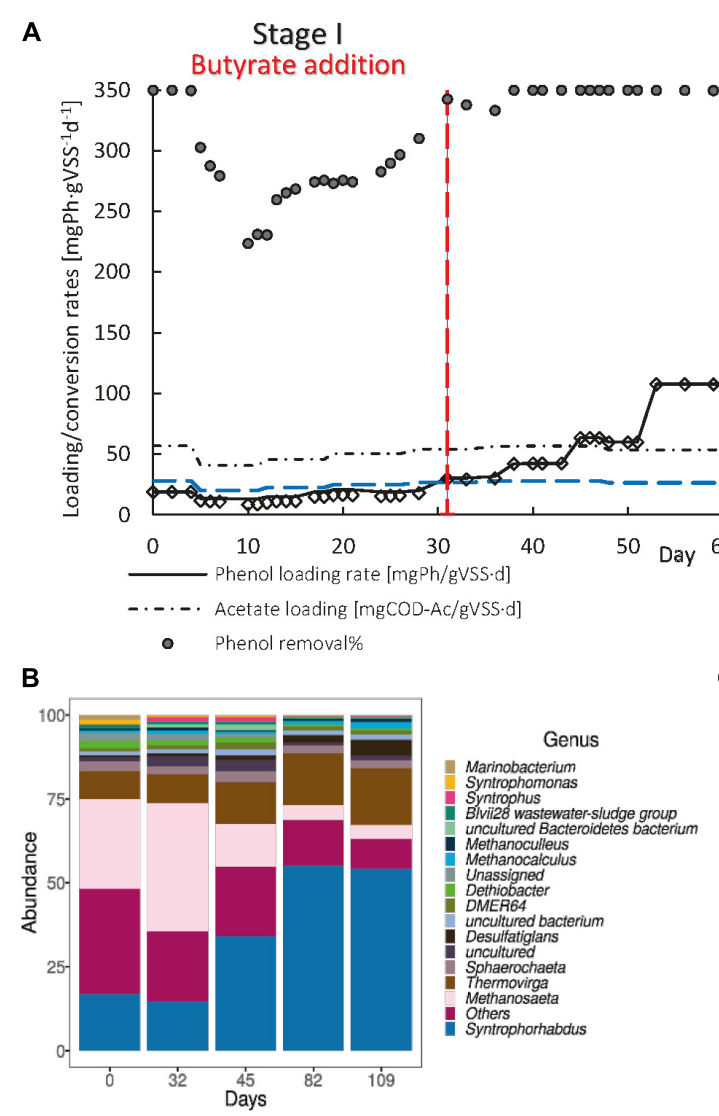

Stage II

Phenol increase

$0 \infty \quad \infty \quad \infty \quad 00000000,100 \%$

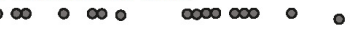


remained as the most abundant methanogenic microorganism, with an average relative abundance of $15 \%$ (days 83 and 100).

During stage III corresponding to the intoxication period (section "AnMBR Operation Toward Phenol as the Main Carbon and Energy Source"), the relative abundance of Syntrophorhabdus sp. kept decreasing with respect to the previous stage to a value of $19.7 \%$, while the methanogen Methanosaeta sp. had a relative abundance of $14.3 \%$. For this stage, the low abundance of Syntrophorhabdus sp. coincided with the observed toxic effect of phenol and the fact that no more phenol but only acetate was present in the influent.

\section{Microbial Community Dynamics in the AnMBR With Acetate as Additional Carbon and Energy Source}

To determine the effect of the increase in the sPhLR and the dosage of acetate as additional CES on the microbial community structure, with a focus on the reported phenol degraders and the methanogens, we analyzed the microbial community structure of the R2(a) during different stages of its operation. We found, similar to R1, that the most abundant bacteria and archaea were Syntrophorhabdus sp. and Methanosaeta, respectively (Figures 5B,C). Same as in the operation of R1, no other genus had a relative abundance higher than 5\%; although, Thermovirga sp. $(4.7 \pm 1.0 \%)$, was the next genus regarding relative abundance.

During stage I, the most abundant microorganism was the phenol degrader Syntrophorhabdus sp. with an average relative abundance of $40.2 \pm 6.4 \%$. The methanogens were mainly represented by Methanosaeta with an average abundance of $10.6 \pm 4.1 \%$. During stage II, after the sPhLR was increased, the relative abundance of Syntrophorhabdus sp. was increased, as well, to a maximum of $62.9 \%$ on day 88 . However, on day 100 , a decrease to $58.3 \%$ was observed, which correlated with the decrease in the phenol removal percentage (section "Canonical Correspondence Analysis"). For the methanogens, Methanosaeta sp. was the main microorganism during this stage with a maximum relative abundance of $7.5 \%$.

During stage III, on day 114 , a further decrease in the relative abundance of Syntrophorhabdus sp. to $41.8 \%$ was observed. However, the methanogen Methanosaeta sp. remained at a similar relative abundance as during stage II.

\section{Microbial Community Dynamics in the AnMBR With the Acetate-Butyrate Mixture}

To determine the effect of the sPhLR and an hydrogen-generating additional CES on the microbial community structure, with a focus on the reported phenol degraders and the methanogens, we analyzed the microbial community structure of the R2(b) during different stages of its operation (Figures 6B,C). For this reactor, the community was, again, mostly represented by the phenol degrader Syntrophorhabdus sp. and the acetoclastic Methanosaeta (>50\%). As it was found in R1 and R2(a), there were no other genera with more than (5\%) of relative abundance. However, in this reactor, the average relative abundance of Thermovirga sp. was $12.3 \pm 3.9 \%$, which suggests that this microorganisms could potentially have a role in the phenol degradation process.
At the beginning of stage I, Syntrophorhabdus sp. and Methanosaeta sp. represented 17.0 and $32.5 \%$ of the microbial community, respectively. On day 32, after the start of the butyrate dosage, and the observed decrease in the phenol removal percentage, there was a slight decrease in Syntrophorhabdus sp. to 14.9\%; that, as discussed in section "Discussion on the Possible Phenol-Degrading-Enhancing Mechanisms," it could possibly be related to an adverse effect of butyrate on the phenol degraders.

During stage II, on day 82 , the relative abundance of Syntrophorhabdus sp. reached a maximum of $55.2 \%$, which was $7 \%$ lower compared to the highest relative abundance of this bacteria when the maximum $\mathrm{SPCR}$ in the reactor operation with acetate as additional CES was reached. Nonetheless, the sPhCR achieved with the acetate-butyrate mixture was $73 \%$ higher than that with only acetate $\left(115 \mathrm{mgPh} \cdot \mathrm{gVSS}^{-1} \mathrm{~d}^{-1}\right)$. For the methanogens, the acetoclastic Methanosaeta sp. remained as the main microorganism. On day 109, the relative abundance of Syntrophorhabdus sp. remained at $54 \%$.

\section{Canonical Correspondence Analysis}

Canonical (or constrained) correspondence analyses (CCA) were performed to assess the changes in the microbial community structure during the operation of the reactors; and therefore, to correlate the effect of the increase in the sPhLR, and the dosage of acetate or the acetate-butyrate mixture with the different microbial communities in R1, R2(a), and R2(b) (Figure 7). CCA is an ordination technique that recovers the response of the community structure to different physical environmental variables, in this case the sPhLR and the sPhCR (Palmer, 1993).

The biplots for each reactor (Figure 7A), in which the vectors indicate the importance of either sPhLR and sPhCR in the ordination process, showed a significant correlation $(p<0.05)$ between the community structures of the biomass of the reactors and the two variables. As it is seen in Figures 7A,B, the community structures at different days $(\mathrm{R} 1=13,31,51$; $\mathrm{R} 2(\mathrm{a})=56,69$ and $80 ; \mathrm{R} 2(\mathrm{~b})=45,82,109)$, corresponding to the points at the right of the biplot, were correlated with a higher sPhLR and sPhCR. In the comparison of the three reactors (Figure 7B), it was noticed that the samples of R2(a) and R2(b) did not group together; however, because of the position of each sample respecting the vectors ( $\mathrm{SPhL}$ and $\mathrm{sPhCR}$ ), it can be concluded that those community structures were more related to higher sPhLR and sPhCR. Regarding these two vectors explaining the environmental variables, it was decided to use both sPhLR and $\mathrm{sPCR}$, because even though sPhLR was the independent variable, $\mathrm{sPhCR}$ represented the biological activity of the biomass.

\section{Discussion on the Possible Phenol-Degrading-Enhancing Mechanisms}

Regarding to the four discussed mechanisms which could enhance the sPhCR, co-metabolism (1) and/or (2) direct usage of acetate as a catabolic substrate by the phenol degraders seems the less likely. As it has been reported, the phenol degrader Syntrophorhabdus sp., excretes acetate through a 

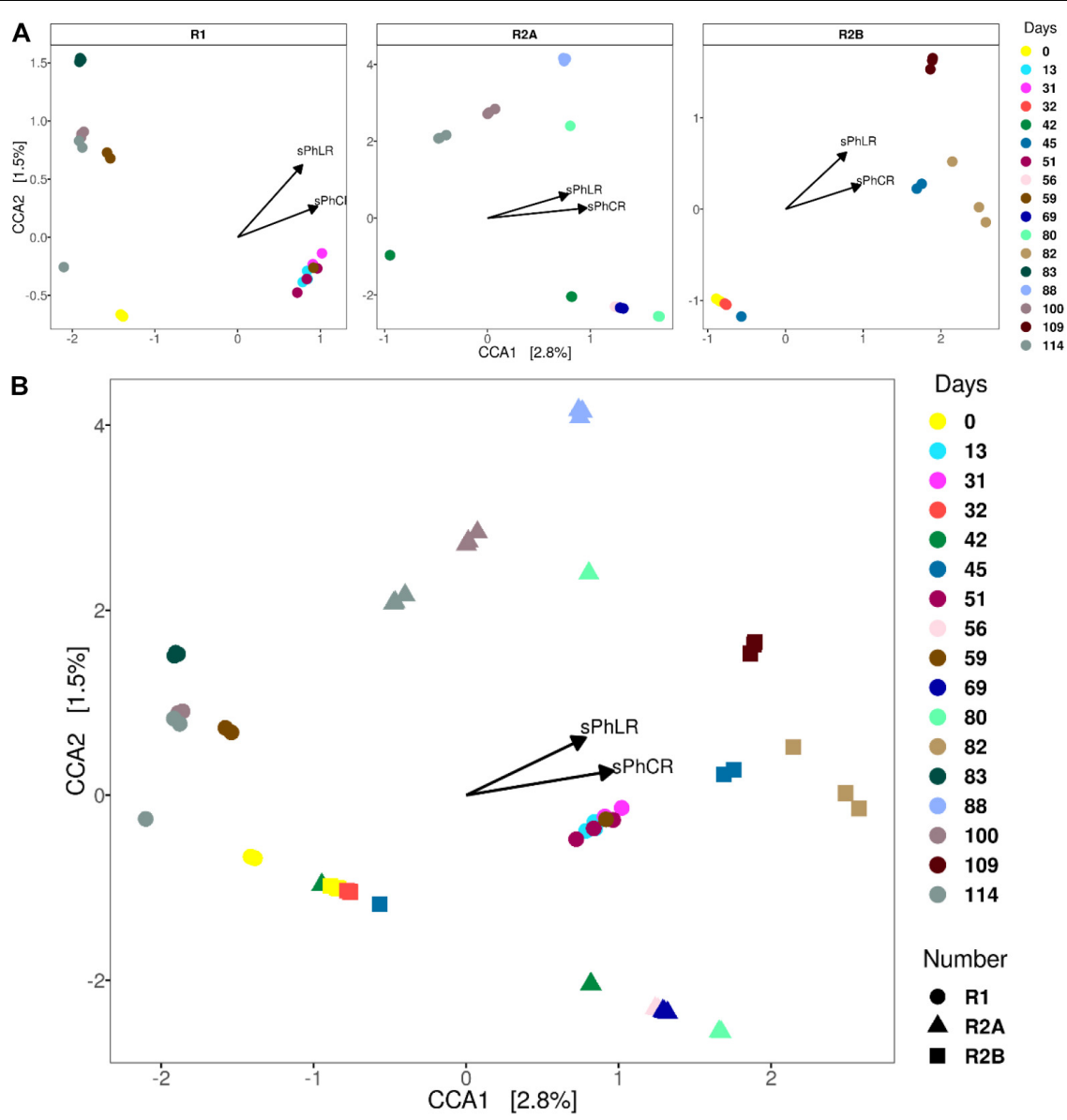

FIGURE 7 |CCAs' for each of the reactors (A) and for all three (B). The samples that correspond to the reactors' operation with increased loading and conversion rates group to right of the biplots.
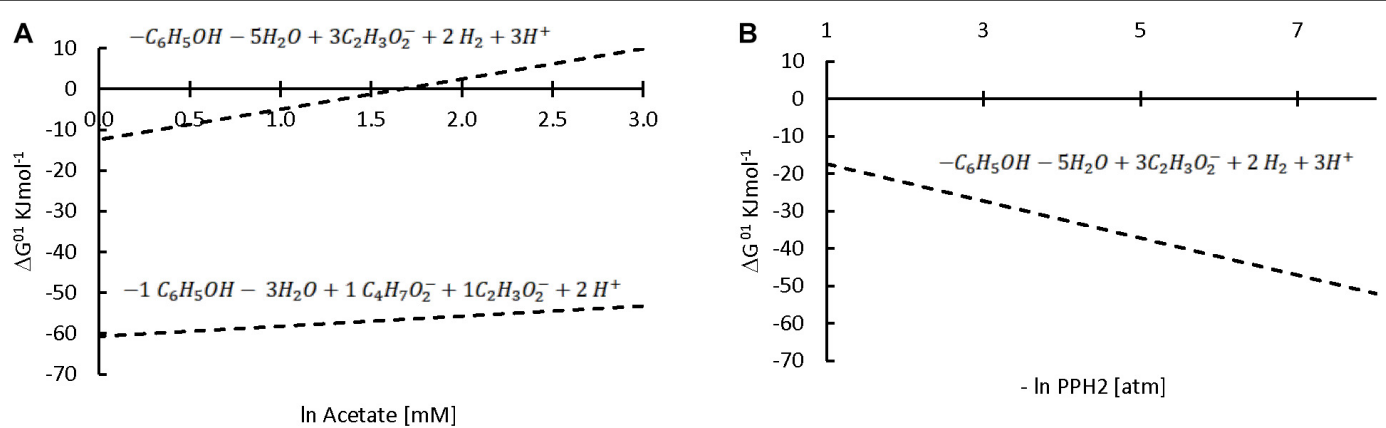

FIGURE 8 | Effect of acetate (upper line) or butyrate (lower line) concentrations (A) or hydrogen partial pressure (B) on the $\Delta \mathrm{G}^{01}$ of the anaerobic phenol degradation reaction. The stoichiometry of each reaction is shown above the corresponding line. Note that the $x$ axis on $(\mathbf{A})$ is $\ln$ while in $(\mathbf{B})$ is -In; therefore, higher concentrations, but lower partial pressures are expected at the right of $x$ axis.

cation-acetate symporter (Nobu et al., 2017). Furthermore, phenol degraders are a physiological population with defined substrates (Eq. S6) (Qiu et al., 2008), being in this case, phenol and not acetate. However, the microbial community analyses results clearly indicate that with an increase in the sPhLR, the percentage of the biomass corresponding to the (reported) phenol degraders increased, reaching values over $50 \%$ of the total relative abundance, either at the order and genus levels (Syntrophorhabdus sp.), of the biomass of R2(a) and R2(b) (Figures 5, 6B,C). Note that the microbial community analyses were based on the study of the 16S rRNA gene, which may introduce inherent biases (Campanaro et al., 2018). 
As well, this analysis does not offer information about the metabolic state of the microorganisms, therefore, presence does not mean activity. Even though, with the addition of acetate or butyrate, the relative abundance of Syntrophorhabdus sp. reached values higher than 50\%, which coincided with the highest $\mathrm{sPhCR}$ achieved by the reactor. This correlation of the microbial community structure with the enhanced conversion was statistically confirmed by the CCA analysis (section "Canonical Correspondence Analysis").

On the other hand, our hypothesis is that the third identified mechanism, syntrophic association, could have played a role in the increase in sPhCR. Two different syntrophic associations with the methanogens are considered, either with the acetoclastics, which were the main methanogens (section "Analysis of the Microbial Community Dynamics During the Operation of the Reactors") and with the hydrogenotrophic. Considering the acetoclastic methanogens, Figure $\mathbf{8}$ shows the effect of the concentration of acetate on the Gibbs free energy change $\left(\Delta \mathrm{G}^{01}\right.$, standard conditions and $\mathrm{pH}=7$ ) of phenol degradation under anaerobic conditions (section "Discussion on the Possible Phenol-Degrading-Enhancing Mechanisms," thermodynamic data Supplementary Material S2, Supplementary Table S2), which shows that a low acetate concentration makes the reaction thermodynamically more favorable. Therefore, an abundant phenol-adapted acetoclastic methanogen population could offer advantages over phenol degradation. Nevertheless, R1 had similar values of the relative abundance of the acetoclastic methanogens (Supplementary Data Sheet S1). Regarding reactor R2(b) and the second syntrophic process, it has been shown that anaerobic mineralization of phenol requires the presence of balanced (syntrophic) associations that guarantee efficient interspecies electron transfer. In these associations, hydrogen-consuming microorganisms, such as the hydrogenotrophic methanogens, may act as the required electron sink (Qiu et al., 2008). For this reason, butyrate was added as additional CES in AnMBR experiment R2(b). However, the reactor fed with butyrate did not show a higher relative abundance of hydrogenotrophic archaea in comparison to the operation of the other reactors (Figure 9). Hydrogenotrophic microorganisms such as Methanoculleus sp. and Methanocalculus sp. were present at an average of $1.76 \pm 0.68 \%$, whereas, when only acetate was dosed as additional CES, hydrogenotrophic methanogens such as Methanobacterium sp. and Methanolinea sp. were found in similar relative abundances (1.42 $\pm 0.42 \%)$. A similar percentage of $1.26 \pm 0.68 \%$ was found for the hydrogenotrophic Methanobacterium in the operation of R1, in which phenol as the sole CES was investigated.

Therefore, we hypothesize that the development of the (acetoclastic) methanogenic population could have enhanced the phenol conversion by keeping the degradation products, e.g., acetate, in a low concentration, allowing the constant conversion of phenol, and consequently promoting an increase of the abundance of the phenol-degrading microorganisms or possibly their specific conversion rate (Eq. S6).

Finally, regarding to the fourth mechanism considered (i.e., an increase in intermediate compounds involved in the conversion

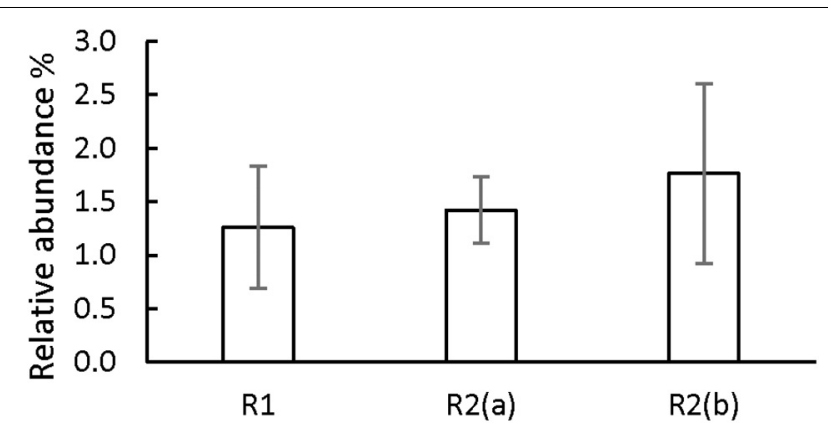

FIGURE 9 | Average relative abundance percentage of the hydrogenotrophic methanogens in the operation of the three AnMBRs. $n=5$ to 10 , bars $\mathrm{Cl} 95 \%$.

of phenolics), it could be possible that an increase in the $\mathrm{HCO}_{3}{ }^{-}$concentration, due to the fermentation of acetate, could have played a role in the enhancement of the sPhCR by promoting the carboxylation step needed for phenol degradation. It has been reported that in the absence of $\mathrm{HCO}_{3} / \mathrm{CO}_{2}$ phenol degradation under anaerobic conditions is hampered (Karlsson et al., 1999) and that the phenylphosphate carboxylase found in Syntrophorhabdus sp. is highly dependent on $\mathrm{HCO}_{3} / \mathrm{CO}_{2}$ (Karlsson et al., 1999; Schühle and Fuchs, 2004; Nobu et al., 2015). However, this hypothesis should be further tested.

\section{CONCLUSION}

The present study showed the feasibility of using AnMBR for the treatment of phenolic wastewater at high sodium concentrations. From the conducted experiments, performed with previously acclimated biomass, the following conclusions can be derived:

- In batch reactors at $8 \mathrm{gNa}{ }^{+} \cdot \mathrm{L}^{-1}$, phenol at a concentration of $0.5 \mathrm{~g} \cdot \mathrm{L}^{-1}$ decreased the SMA with $27 \%$ in comparison to the control tests without phenol. A maximum sPhCR of $17.8 \pm 2.6 \mathrm{mgPh} \cdot \mathrm{gVSS}^{-1} \mathrm{~d}^{-1}$ was determined for an initial phenol concentration of $500 \mathrm{mg} \cdot \mathrm{L}^{-1}$.

- In the AnMBR, a stable sPhCR of $40 \mathrm{mgPh} \cdot \mathrm{gVSS}^{-1} \mathrm{~L}^{-1}$ was measured when phenol contributed to $80 \%$ of the total COD. However, the sPhCR could not be maintained when phenol was the sole CES.

- In the AnMBR, when acetate was added as additional CES, a maximum sPhCR of $115 \mathrm{mgPh} \cdot \mathrm{gVSS}^{-1} \mathrm{~L}^{-1}$ was determined.

- The highest $\mathrm{sPhCR}$ of $200 \mathrm{mgPh} \cdot \mathrm{gVSS}^{-1} \mathrm{~L}^{-1}$ was found when a 2:1 acetate-butyrate mixture, based on COD, was fed to the AnMBR.

- During the operation of the reactors, the most abundant microorganisms were the phenol degrader Syntrophorhabdus sp. and the acetoclastic methanogen Methanosaeta sp., making more than $50 \%$ of the microbial community. Seemingly, there was a correlation $(p<0.05)$ between the increase in the sPhLR and the increase in the relative abundance of Syntrophorhabdus sp. 


\section{DATA AVAILABILITY STATEMENT}

The original contributions presented in the study are publicly available. This data can be found in NCBI under accession number PRJNA663299.

\section{AUTHOR CONTRIBUTIONS}

VG conceptualized and designed the batch and reactor experiments, carried out the batch experiments, gathered, and analyzed the data, directed and supervised the operation of reactors, analyzed their data, planned and worked the samples for the microbial community analysis, and wrote the manuscript. JM conceptualized and designed the batch and reactor experiments, critically reviewed and provided feedback for the data analysis. LF designed and operated partially the reactor experiments, carried out analytical methods, and analyzed the data. KQ operated partially the reactors and performed laboratory analyses. DC-G did the bioinformatics analyses and performed the microbial community analysis. JM, HS, and JvL provided feedback that helped shape the research, experiments, and data analysis, and critically revised the manuscript. All authors have read and approved the final manuscript.

\section{REFERENCES}

Astals, S., Batstone, D. J., Tait, S., and Jensen, P. D. (2015). Development and validation of a rapid test for anaerobic inhibition and toxicity. Water Res. 81, 208-215. doi: 10.1016/j.watres.2015.05.063

Batstone, D. J., Keller, J., Angelidaki, I., Kalyuzhnyi, S. V., Pavlostathis, S. G., Rozzi, A., et al. (2002). The IWA anaerobic digestion model no 1 (ADM1). Water Sci. Technol. 45, 65-73. doi: 10.2166/wst.2002.0292

Bertrand, J.-C., Doumenq, P., Guyoneaud, R., Marrot, B., Martin-Laurent, F., Matheron, R., et al. (2015). "Applied Microbial Ecology and Bioremediation," in Environmental Microbiology: Fundamentals and Applications: Microbial Ecology, eds J.-C. Bertrand, P. Caumette, P. Lebaron, R. Matheron, P. Normand, and T. Sime-Ngando (Dordrecht: Springer Netherlands), 659-753. doi: 10. 1007/978-94-017-9118-2_16

Blum, D. J. W., Hergenroeder, R., Parkin, G. F., and Speece, R. E. (1986). Anaerobic treatment of coal conversion wastewater constituents: biodegradability and Toxicity. J. (Water Pollut. Control Fed.) 58, 122-131.

Bolaños, R. M. L., Varesche, M. B. A., Zaiat, M., and Foresti, E. (2001). Phenol degradation in horizontal-flow anaerobic immobilized biomass (HAIB) reactor under mesophilic conditions. Water Sci. Technol. 44, 167-174. doi: 10.2166/wst. 2001.0212

Bolyen, E., Rideout, J. R., Dillon, M. R., Bokulich, N. A., Abnet, C. C., AlGhalith, G. A., et al. (2019). Reproducible, interactive, scalable and extensible microbiome data science using QIIME 2. Nat. Biotechnol. 37, 852-857. doi: 10.1038/s41587-019-0209-9

Callahan, B. J., Mcmurdie, P. J., Rosen, M. J., Han, A. W., Johnson, A. J., and Holmes, S. P. (2016). DADA2: high-resolution sample inference from Illumina amplicon data. Nat. Methods 13, 581-583. doi: 10.1038/nmeth.3869

Campanaro, S., Treu, L., Kougias, P. G., Zhu, X., and Angelidaki, I. (2018). Taxonomy of anaerobic digestion microbiome reveals biases associated with the applied high throughput sequencing strategies. Sci. Rep. 8:1926. doi: 10.1038/ s41598-018-20414-0

Carbajo, J. B., Boltes, K., and Leton, P. (2010). Treatment of phenol in an anaerobic fluidized bed reactor (AFBR): continuous and batch regime. Biodegradation 21, 603-613. doi: 10.1007/s10532-010-9328-1

\section{FUNDING}

This research was supported by the Dutch Technology Foundation (STW, Project No 13348), which is 528 part of the Netherlands Organisation for Scientific Research (NWO), partly funded by the Dutch 529 Ministry of Economic Affairs. This research is co-sponsored by Evides Industriewater and Paques B.V.

\section{ACKNOWLEDGMENTS}

We thank the lab technicians Mohammed Jafar and Armand Middeldorp for their technical support, and Flor A. García Rea and Pamela S. Ceron Chafla for their help with the graphical design. VG thanks 1) Alexander Hendriks and Xuedong Zhang for all the discussions, and 2) the Mexican National Council of Science and Technology (CONACyT) for granting him the Ph.D. Scholarship No. 410669.

\section{SUPPLEMENTARY MATERIAL}

The Supplementary Material for this article can be found online at: https://www.frontiersin.org/articles/10.3389/fmicb. 2020.604173/full\#supplementary-material

Chang, B. V., Chiang, F., and Yuan, S. Y. (2005). Anaerobic degradation of nonylphenol in sludge. Chemosphere 59, 1415-1420. doi: 10.1016/j. chemosphere.2004.12.055

Chang, Y.-J., Nishio, N., and Nagai, S. (1995). Characteristics of granular methanogenic sludge grown on phenol synthetic medium and methanogenic fermentation of phenolic wastewater in a UASB reactor. J. Ferment. Bioeng. 79, 348-353. doi: 10.1016/0922-338x(95)93993-t

Chen, Y., Cheng, J. J., and Creamer, K. S. (2008). Inhibition of anaerobic digestion process: a review. Bioresour. Technol. 99, 4044-4064. doi: 10.1016/j.biortech. 2007.01.057

Collins, G., Foy, C., Mchugh, S., Mahony, T., and O'flaherty, V. (2005). Anaerobic biological treatment of phenolic wastewater at $15-18^{\circ} \mathrm{C}$. Water Res. 39, 16141620. doi: 10.1016/j.watres.2005.01.017

Dahle, H., and Birkeland, N.-K. (2006). Thermovirga lienii gen. nov., sp. nov., a novel moderately thermophilic, anaerobic, amino-acid-degrading bacterium isolated from a North Sea oil well. Int. J. Syst. Evol. Microbiol. 56, 1539-1545. doi: 10.1099/ijs.0.63894-0

De Amorim, E. L. C., Sader, L. T., and Silva, E. L. (2015). Effects of the OrganicLoading rate on the performance of an Anaerobic Fluidized-Bed reactor treating synthetic wastewater containing phenol. J. Environ. Eng. 141, 04015022. doi: 10.1061/(asce)ee.1943-7870.0000952

Dereli, R. K., Ersahin, M. E., Ozgun, H., Ozturk, I., Jeison, D., Van Der Zee, F., et al. (2012). Potentials of anaerobic membrane bioreactors to overcome treatment limitations induced by industrial wastewaters. Bioresour. Technol. 122, 160-170. doi: 10.1016/j.biortech.2012.05.139

Fang, H. H., Liu, Y., Ke, S. Z., and Zhang, T. (2004). Anaerobic degradation of phenol in wastewater at ambient temperature. Water Sci. Technol. 49, 95-102. doi: 10.2166/wst.2004.0028

Fang, H. H., and Zhou, G.-M. (2000). Degradation of phenol and p-cresol in reactors. Water Sci. Technol. 42, 237-244. doi: 10.2166/wst.2000.0519

Fang, H. H. P., and Chan, O.-C. (1997). Toxicity of phenol towards anaerobic biogranules. Water Res. 31, 2229-2242. doi: 10.1016/S0043-1354(97)00069-9

Fang, H. H. P., Chen, T., Li, Y.-Y., and Chui, H.-K. (1996). Degradation of phenol in wastewater in an upflow anaerobic sludge blanket reactor. Water Res. 30, 1353-1360. doi: 10.1016/0043-1354(95)00309-6 
Franchi, O., Rosenkranz, F., and Chamy, R. (2018). Key microbial populations involved in anaerobic degradation of phenol and p-cresol using different inocula. Electron. J. Biotechnol. 35, 33-38. doi: 10.1016/j.ejbt.2018.08.002

Fuchs, G. (2008). Anaerobic metabolism of aromatic compounds. Ann. N. Y. Acad. Sci. 1125, 82-99. doi: 10.1196/annals.1419.010

Fuchs, G., Boll, M., and Heider, J. (2011). Microbial degradation of aromatic compounds-from one strategy to four. Nat. Rev. Microbiol. 9, 803-816. doi: 10.1038/nrmicro2652

Gali, V. S., Kumar, P., and Mehrotra, I. (2006). Biodegradation of phenol with wastewater as a cosubstrate in upflow Anaerobic Sludge Blanket. J. Environ. Eng. 132, 1539-1542. doi: 10.1061/(ASCE)0733-93722006132:11(1539

Gibson, J., and Harwood, C. S. (2002). Metabolic diversity in aromatic compound utilization by Anaerobic Microbes. Ann. Rev. Microbiol. 56, 345-369. doi: 10. 1146/annurev.micro.56.012302.160749

Guiot, S. R., Tawfiki-Hájji, K., and Lépine, F. (2000). Immobilization strategies for bioaugmentation of anaerobic reactors treating phenolic compounds. Water Sci. Technol. 42, 245-250. doi: 10.2166/wst.2000.0520

Han, S.-B., Wang, R.-J., Yu, X.-Y., Su, Y., Sun, C., Fu, G.-Y., et al. (2016). Marinobacterium zhoushanense sp. nov., isolated from surface seawater. Int. J. Syst. Evol. Microbiol. 66, 3437-3442. doi: 10.1099/ijsem.0.001213

Hanselmann, K. W. (1991). Microbial energetics applied to waste repositories. Experientia 47, 645-687. doi: 10.1007/BF01958816

He, H., Chen, Y., Li, X., Cheng, Y., Yang, C., and Zeng, G. (2017). Influence of salinity on microorganisms in activated sludge processes: a review. Int. Biodeterior. Biodegradation 119, 520-527. doi: 10.1016/j.ibiod.2016.10.007

Heijnen, J. J., and Kleerebezem, R. (2010). "Bioenergetics of Microbial Growth," in Encyclopedia of Industrial Biotechnology, ed. M. C. Flickinger (Hoboken, NJ: John Wiley \& Sons), 1-66. doi: 10.1002/9780470054581.eib084

Hendriks, A. T. W. M., Van Lier, J. B., and De Kreuk, M. K. (2018). Growth media in anaerobic fermentative processes: The underestimated potential of thermophilic fermentation and anaerobic digestion. Biotechnol. Adv. 36, 1-13. doi: 10.1016/j.biotechadv.2017.08.004

Horvath, R. S. (1972). Microbial co-metabolism and the degradation of organic compounds in nature. Bacteriol. Rev. 36, 146-155. doi: 10.1128/mmbr.36.2. 146-155.1972

Ji, Q., Tabassum, S., Hena, S., Silva, C. G., Yu, G., and Zhang, Z. (2016). A review on the coal gasification wastewater treatment technologies: past, present and future outlook. J. Clean. Prod. 126, 38-55. doi: 10.1016/j.jclepro.2016.02.147

Karlsson, A., Ejlertsson, J., Nezirevic, D., and Svensson, B. H. (1999). Degradation of phenol under meso- and thermophilic, anaerobic conditions. Anaerobe 5, 25-35. doi: 10.1006/anae.1998.0187

Kennes, C., Mendez, R., and Lema, J. M. (1997). Methanogenic degradation of p-cresol in batch and in continuous UASB reactors. Water Res. 31, 1549-1554. doi: 10.1016/S0043-1354(96)00156-X

Kleerebezem, R. (1999). Anaerobic Treatmen of Phthalates, Microbiological and Technological Aspects. PhD. thesis, WUR: Wageningen.

Knoll, G., and Winter, J. (1987). Anaerobic degradation of phenol in sewage sludge. Appl. Microbiol. Biotechnol. 25, 384-391. doi: 10.1007/bf00252552

Lao, S.-G. (2002). Mechanisms of granular activated carbon anaerobic fluidizedbed process for treating phenols wastewater. J. Environ. Sci. (China) 14, 132-135.

Lay, J.-J., and Cheng, S.-S. (1998). Influence of hydraulic loading rate on UASB reactor treating phenolic wastewater. J. Environ. Eng. 124, 829-837. doi: 10. 1061/(asce)0733-9372(1998)124:9(829)

Li, Y., Tabassum, S., Chu, C., and Zhang, Z. (2017). Inhibitory effect of high phenol concentration in treating coal gasification wastewater in anaerobic biofilter. J. Environ. Sci. 64, 207-215. doi: 10.1016/j.jes.2017.06.001

Li, Y., Tabassum, S., and Zhang, Z. (2016). An advanced anaerobic biofilter with effluent recirculation for phenol removal and methane production in treatment of coal gasification wastewater. J. Environ. Sci. 47, 23-33. doi: 10.1016/j.jes.2016. 03.012

Liang, D., and Fang, H. H. P. (2010). "Anaerobic Treatment of Phenolic Wastewaters," in Environmental Anaerobic Technology, ed. H. H. P. Fang (Singapore: World Scientific Publishing), 185-205. doi: $10.1142 / 9781848165434 \_0009$

Lin, H., Peng, W., Zhang, M., Chen, J., Hong, H., and Zhang, Y. (2013). A review on anaerobic membrane bioreactors: applications, membrane fouling and future perspectives. Desalination 314, 169-188. doi: 10.1016/j.desal.2013.01.019
Maiti, D., Ansari, I., Rather, M. A., and Deepa, A. (2019). Comprehensive review on wastewater discharged from the coal-related industries-characteristics and treatment strategies. Water Sci. Technol. 79, 2023-2035. doi: 10.2166/wst.2019. 195

Mcmurdie, P. J., and Holmes, S. (2013). phyloseq: an R package for reproducible interactive analysis and graphics of microbiome census data. PLoS One 8:e61217. doi: 10.1371/journal.pone.0061217

Muñoz Sierra, J. D., Lafita, C., Gabaldón, C., Spanjers, H., and Van Lier, J. B. (2017). Trace metals supplementation in anaerobic membrane bioreactors treating highly saline phenolic wastewater. Bioresour. Technol. 234, 106-114. doi: 10.1016/j.biortech.2017.03.032

Muñoz Sierra, J. D., Oosterkamp, M. J., Wang, W., Spanjers, H., and Van Lier, J. B. (2018). Impact of long-term salinity exposure in anaerobic membrane bioreactors treating phenolic wastewater: performance robustness and endured microbial community. Water Res. 141, 172-184. doi: 10.1016/j.watres.2018.05. 006

Muñoz Sierra, J. D., Oosterkamp, M. J., Wang, W., Spanjers, H., and Van Lier, J. B. (2019). Comparative performance of upflow anaerobic sludge blanket reactor and anaerobic membrane bioreactor treating phenolic wastewater: overcoming high salinity. Chem. Eng. J. 366, 480-490. doi: 10.1016/j.cej.2019.02.097

Munoz Sierra, J. D., Wang, W., Cerqueda-Garcia, D., Oosterkamp, M. J., Spanjers, H., and Van Lier, J. B. (2018). Temperature susceptibility of a mesophilic anaerobic membrane bioreactor treating saline phenol-containing wastewater. Chemosphere 213, 92-102. doi: 10.1016/j.chemosphere.2018.09.023

Nobu, M. K., Narihiro, T., Hideyuki, T., Qiu, Y. L., Sekiguchi, Y., Woyke, T., et al. (2015). The genome of Syntrophorhabdus aromaticivorans strain UI provides new insights for syntrophic aromatic compound metabolism and electron flow. Environ. Microbiol. 17, 4861-4872. doi: 10.1111/1462-2920.12444

Nobu, M. K., Narihiro, T., Liu, M., Kuroda, K., Mei, R., and Liu, W. T. (2017). Thermodynamically diverse syntrophic aromatic compound catabolism. Environ. Microbiol. 19, 4576-4586. doi: 10.1111/1462-2920.13922

Olguin-Lora, P., Puig-Grajales, L., and Razo-Flores, E. (2003). Inhibition of the acetoclastic methanogenic activity by phenol and alkyl phenols. Environ. Technol. 24, 999-1006. doi: 10.1080/09593330309385638

Palmer, M. W. (1993). Putting things in even better order: the advantages of canonical correspondence analysis. Ecology 74, 2215-2230. doi: 10.2307/ 1939575

Puig-Grajales, L., Rodríguez-Nava, O., and Razo-Flores, E. (2003). Simultaneous biodegradation of a phenol and 3, 4-dimethylphenol mixture under denitrifying conditions. Water Sci. Technol. 48, 171-178. doi: 10.2166/wst.2003.0389

Qiu, Y. L., Hanada, S., Ohashi, A., Harada, H., Kamagata, Y., and Sekiguchi, Y. (2008). Syntrophorhabdus aromaticivorans gen. nov., sp. nov., the first cultured anaerobe capable of degrading phenol to acetate in obligate syntrophic associations with a hydrogenotrophic methanogen. Appl. Environ. Microbiol. 74, 2051-2058. doi: 10.1128/aem.02378-07

Quast, C., Pruesse, E., Yilmaz, P., Gerken, J., Schweer, T., Yarza, P., et al. (2013). The SILVA ribosomal RNA gene database project: improved data processing and web-based tools. Nucleic Acids Res. 41, D590-D596. doi: 10.1093/nar/gks1219

Ramakrishnan, A., and Gupta, S. K. (2008). Effect of hydraulic retention time on the biodegradation of complex phenolic mixture from simulated coal wastewater in hybrid UASB reactors. J. Hazard. Mater. 153, 843-851. doi: 10. 1016/j.jhazmat.2007.09.034

Razo-Flores, E., Iniestra-González, M., Field, J. A., Olgu-Lora, P., and PuigGrajales, L. (2003). Biodegradation of mixtures of phenolic compounds in an upward-flow anaerobic sludge blanket reactor. J. Environ. Eng. 129, 999-1006. doi: 10.1061/(asce)0733-9372(2003)129:11(999)

Rognes, T., Flouri, T., Nichols, B., Quince, C., and Mahe, F. (2016). VSEARCH: a versatile open source tool for metagenomics. PeerJ 4:e2584. doi: 10.7717/peerj. 2584

Russell, J. B., and Cook, G. M. (1995). Energetics of bacterial growth: balance of anabolic and catabolic reactions. Microbiol. Rev. 59, 48-62. doi: 10.1128/mmbr. 59.1.48-62.1995

Sancinetti, G. P., Sader, L., Varesche, M. B. A., Amorim, E. L. C. D., Omena, S. P. F. D., and Silva, E. (2012). Phenol degradation in an anaerobic fluidized bed reactor packed with low density support materials. Braz. J. Chem. Eng. 29, 87-98. doi: 10.1590/s0104-66322012000100010

Schink, B., Philipp, B., and Muller, J. (2000). Anaerobic degradation of phenolic compounds. Naturwissenschaften $87,12-23$. doi: 10.1007/s001140050002 
Schühle, K., and Fuchs, G. (2004). Phenylphosphate carboxylase: a New C-C Lyase involved in anaerobic phenol metabolism in Thauera Aromatica. J. Bacteriol. 186, 4556-4567. doi: 10.1128/JB.186.14.4556-4567.2004

Scully, C., Collins, G., and O'flaherty, V. (2006). Anaerobic biological treatment of phenol at $9.5-15^{\circ} \mathrm{C}$ in an expanded granular sludge bed (EGSB)-based bioreactor. Water Res. 40, 3737-3744. doi: 10.1016/j.watres.2006.08.023

Singer, P. C., Pfaender, F. K., Chinchilli, J., Maciorowski Iii, A. F., and Lamb, J. C. III (1978). Assessment of Coal Conversion Wastewaters: Characterization and Preliminary Biotreatability, Technical Report. Chapel Hill, NC: University of North Carolina at Chapel Hill.

Suidan, M. T., Najm, I. N., Pfeffer, J. T., and Wang, Y. T. (1988). Anaerobic biodegradation of phenols inhibition kinetics and system stability. J. Environ. Eng. 114, 1359-1376. doi: 10.1061/(asce)0733-9372(1988)114:6(1359)

Tay, J.-H., He, Y.-X., and Yan, Y.-G. (2000). Anaerobic biogranulation using phenol as the sole carbon source. Water Environ. Res. 72, 189-194. doi: 10.2175/ 106143000x137275

Tay, J.-H., He, Y.-X., and Yan, Y.-G. (2001). Improved anaerobic degradation of phenol with supplemental glucose. J. Environ. Eng. 127, 38-45. doi: 10.1061/ (asce)0733-9372(2001)127:1(38)

Van Lier, J., Van Der Zee, F., Frijters, C., and Ersahin, M. (2015). Celebrating 40 years anaerobic sludge bed reactors for industrial wastewater treatment. Rev. Environ. Sci. Biotechnol. 14, 681-702. doi: 10.1007/s11157-015-9375-5

Veeresh, G. S., Kumar, P., and Mehrotra, I. (2005). Treatment of phenol and cresols in upflow anaerobic sludge blanket (UASB) process: a review. Water Res. 39, 154-170. doi: 10.1016/j.watres.2004.07.028

Wackett, L. P. (1996). Co-metabolism: is the emperor wearing any clothes? Curr. Opin. Biotechnol. 7, 321-325. doi: 10.1016/S0958-1669(96)80038-3
Wang, J., Wu, B., Sierra, J. M., He, C., Hu, Z., and Wang, W. (2020). Influence of particle size distribution on anaerobic degradation of phenol and analysis of methanogenic microbial community. Environ. Sci. Pollut. Res. 27, 10391-10403. doi: $10.1007 / \mathrm{s} 11356-020-07665-\mathrm{z}$

Wang, W., Han, H., Yuan, M., and Li, H. (2010). Enhanced anaerobic biodegradability of real coal gasification wastewater with methanol addition. J. Environ. Sci. 22, 1868-1874. doi: 10.1016/S1001-0742(09)60 $327-2$

Wang, W., Wu, B., Pan, S., Yang, K., Hu, Z., and Yuan, S. (2017). Performance robustness of the UASB reactors treating saline phenolic wastewater and analysis of microbial community structure. J. Hazard. Mater. 331, 21-27. doi: 10.1016/j.jhazmat.2017.02.025

Zhou, G.-M., and Fang, H. H. P. (1997). Co-degradation of phenol and m-cresol in a UASB reactor. Bioresour. Technol. 61, 47-52. doi: 10.1016/S0960-8524(97) 84698-6 doi: 10.1016/s0960-8524(97)84698-6

Conflict of Interest: The authors declare that the research was conducted in the absence of any commercial or financial relationships that could be construed as a potential conflict of interest.

Copyright (C) 2020 García Rea, Muñoz Sierra, Fonseca Aponte, Cerqueda-Garcia, Quchani, Spanjers and van Lier. This is an open-access article distributed under the terms of the Creative Commons Attribution License (CC BY). The use, distribution or reproduction in other forums is permitted, provided the original author(s) and the copyright owner(s) are credited and that the original publication in this journal is cited, in accordance with accepted academic practice. No use, distribution or reproduction is permitted which does not comply with these terms. 